\title{
Transport of Microorganisms in the Terrestrial Subsurface: In Situ and Laboratory Methods
}

\author{
RONALD W HARVEY AND HAUKE HARMS
}

\author{
Ref: In Hurst, C.J., Knudsen, G.R., McInerney, M.J., Stetzenback, L.D., Crawford, R.L., eds., Manual of \\ Environmental Microbiology, $2^{\text {nd }}$ Edition: Washington, ASM Press, pp. 753-776.
}

\section{$\underline{69}$}

Although the use of microbial tracers has been instrumental in developing a better understanding of groundwater movement in many types of aquifers $(1,17,34,141,149,189$, 190, 239), the importance of studying the transport behavior of the microorganisms themselves is now very apparent. This is due largely to an increasing dependence on limited and fragile groundwater resources. In particular, widespread contamination of shallow drinking-water aquifers by microbial pathogens and chemical wastes has led to increased interest in the factors that control subsurface microbial transport. The movement of nonindigenous bacteria, viruses, and protozoa through aquifers has been a public health concern in the United States (see chapter 71), where inadvertent contamination of water supply wells by microbial pathogens contributes significantly to the total number of waterborne disease outbreaks (139). Deliberate additions of nonindigenous populations of bacteria to organically contaminated aquifer sediments are now conducted to enhance in situ bioremediation rates in laboratory- and fieldscale bioaugmentation experiments (191, 194, 210, 237, 238) and to increase oil recovery from less transmissive zones by selective bacterial plugging of more permeable strata (see chapter 70). The success of bioaugmentation can depend as much on the ability of the introduced microorganisms to reach the contaminants as on in situ survival and factors affecting contaminant bioavailability (204a) such as its pore-scale distribution (71) and diffusion limitations (72). Transport properties of introduced bacteria in groundwater can play major roles in the transmission of some waterborne diseases (21), in the success of microbially enhanced oil recovery processes $(39,94,138)$, in the mobility of surface-active or hydrophobic groundwater contaminants $(38,96,115,132)$, in pore clogging $(14,226)$, and in the potential subsurface dissemination of genetically engineered bacteria for biorestoration (220). However, many of the factors controlling subsurface microbial transport are still poorly understood.

To better study the controls of microbial transport, it has been necessary to improve available methodology for investigating microbial transport behavior in the laboratory and in the field. The many physical, chemical, and biological factors that affect microbial transport through aquifer materials (75) have necessitated refinement of techniques, allowing observations under more controlled experimental conditions. In this chapter, laboratory and field techniques for studying microbial transport behavior in aquifer materials and model porous media are described and discussed.

\section{FIELD VERSUS LABORATORY STUDIES}

Although most studies delineating the controls of subsurface microbial transport are performed in the laboratory, advances in our understanding of microbial transport behavior would clearly benefit from an iterative approach that combines laboratory and field investigation (Fig. 1). Column studies provide a greater degree of control and, therefore, are useful for providing detailed mechanistic information about specific processes affecting microbial transport. Also, columns can be designed to more nearly meet initial boundary conditions from microbial transport models. However, they cannot account for the combined effects of the various controls that govern microbial mobility in situ. There are many factors, in addition to the hydrological characteristics of the aquifer itself, which control the movement of microorganisms in groundwater. For bacteria, these biotic and abiotic factors include growth, predation by protists, possible parasitism by bacteriophage, motility, lysis under unfavorable conditions, changes in cell size and propensity for attachment to solid surfaces in response to alterations in nutrient conditions, spore formation in some gram-positive species, reversible and irreversible attachment to solid surfaces, detachment from surfaces, aggregation, and straining (75). Many of these processes are interrelated through other factors, poorly understood, and/or difficult to describe mathematically. Therefore, it is desirable to combine laboratory experiments, which allow better delineation of individual processes, with field studies, which provide a framework in which the applicability of laboratory-derived results can be evaluated under natural conditions.

Flow-through column experiments have provided useful and detailed information on many processes governing microbial transport behavior (Table 1). However, it is difficult to extrapolate laboratory results back to the subsurface environment for several reasons. First, the unavoidable destruction of secondary pore structure that results from manual or mechanical repacking of unsaturated or saturated subsurface materials substantively diminishes microbial transport $(80,207)$. Hydrodynamic dispersion, which is small (i.e., a few centimeters) and therefore relatively 
FELD WORK

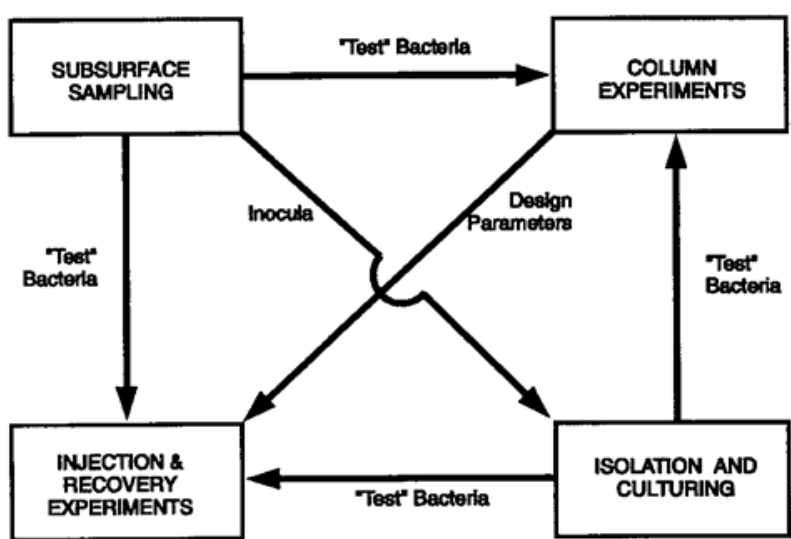

FIGURE 1 Integrated field and laboratory experimental approach to investigating the transport behavior of microorganisms in groundwater environments.

unimportant to microbial transport at the column scale (224), can be very large (i.e., many meters) in field-scale experiments (124). Finally, flow velocities used in columns are usually much higher than those commonly observe in the field $\left(<1 \mathrm{~m} \bullet\right.$ day $\left.^{-1}\right)$. This is largely because pumps typically employed in column experiments cannot deliver accurately and steadily at very low volumetric flow rates. Such disparities in flow can affect the number of attachment opportunities and the thickness of the hydrodynamic boundary layers (the zone of lower-velocity water immediately adjacent to grain surfaces). Indeed, even modest (e.g., several fold) changes in flow velocity significantly affect the degrees of immobilization $(30,32,60,85)$ and pore-size exclusion (32) to which bacteria are subject in saturated porous media. Although one cannot extrapolate microbial transport potential determined from column studies directly to the field-scale, deposition parameters calculated from experiments with small flow-through columns containing sediments collected from a number of different points in a granular aquifer may still be useful for predictions of fieldscale transport by using a probabilistic model (24).

\section{BIOLOGICAL AND PHYSICOCHEMICAL FACTORS}

\section{Chemical Considerations}

It has been shown that subtle differences in groundwater and/or surface chemistry can substantively affect the magnitude of microbial transport through aquifer sediments and the reversibility of microbial attachment (169). Therefore, in comparing the apparent transport behavior of microorganisms in small-scale field or laboratory studies, it is important to separate out the effects of intentional and/or unintentional differences in chemistry.

It may be important to account for or control bacterial growth during subsurface transport in injection and recovery experiments. Uncontaminated aquifers are generally extremely oligotrophic. Consequently, bacterial growth in groundwater is generally very slow (5) and difficult to measure accurately by available methods (77). However, substantive bacterial growth can occur during transport downgradient in small-scale transport experiments as a re- sult of the inadvertent introduction of dissolved organic matter (DOM) during injection into aquifers that are limited with respect to carbon. The introduction of labile DOM is particularly problematic when cultured bacteria are used as an inoculum, because it is difficult to stop residual broth nutrients and bacterial metabolites and lysates from contaminating the injectate. Inadvertent contamination with DOM during the introduction of cultured isolates may be lessened by a priori resuspension in non-growth medium (42). Also, it is helpful to monitor changes in abundance over the experimental time course of labeled bacteria in collected samples held at the in situ temperature (76).

Changes in ionic strength (I) during transport studies may occur inadvertently as a result of using halides as conservative tracers and may lead to density-induced sinking of the tracer cloud (159). Substantive increases in I because of injection of high concentrations of halide tracers can also result in overestimations of microbial attachment. The general observations of increasing attachment with increasing I may be predicted from the extended (228) DerjaguinLandau-Verwey-Overbeek (DLVO) theory of colloid stability (192), because the microorganisms and surfaces employed are both negatively charged at the $\mathrm{pH}$ at which most microbial transport studies are run and the interactions are largely electrostatic. The observation of increased attachment to grain surfaces with increasing I was well documented for viruses by the mid-1970s $(50,123,235)$ and for bacteria in porous media by the 1990s (see references 30, 46, 55, 64, 99, 153, and 216). However, there may be exceptions. For example, adhesion to negatively charged glass of a positively charged $\left(\mathrm{pH}_{\mathrm{IEP}}=11\right)$ clinical isolate, Stenotrophomonas maltophilia 70401, was shown to decrease with increasing I within the range of 0.001 to $1 \mathrm{M}$ (109). Changes in the extent of bacterial attachment in aquifer sediments in response to substantive changes in I should be most pronounced where the initial I is low. For many aquifers, particularly those used as sources of potable water, I can be $\leq 10^{-3} \mathrm{M}$ (see e.g., reference 198), and considerable care must be taken when adding salts as tracers during injection and recovery experiments. In such aquifers, deuterated (183) or tritiated (151) water might be considered as alternative hydrologic tracers. Finally, it is important to avoid addition of salts containing bivalent cations, because bacterial attachment to granular media is very sensitive to their presence (203).

\section{Physiological Considerations}

It is becoming more evident that the manner in which microorganisms are handled prior to an injection and recovery test can affect their subsequent transport behavior in the aquifer. It is important to recognize that a number of transport-determining bacterial characteristics (e.g., cell size, hydrophobicity, motility, and exopolymer production) can be affected by nutrient availability prior to introduction of the microorganisms to granular media (82). Changes in nutrient conditions can also be accompanied by alterations in amounts of storage molecules such as poly- $\beta$ hydroxybutyrate (166) and glycogen (144), which can affect buoyant density (73). Substantive differences in both specific gravity and cell size between near-neutral buoyant $\left(\leq 1.02 \mathrm{~g} \bullet \mathrm{cm}^{-1}\right)$ uncultured groundwater bacteria $(81)$ and cultured groundwater isolates $(81,231)$ have been reported. Therefore, it is not surprising that broth-grown microorganisms reintroduced into a carbon-limited aquifer 


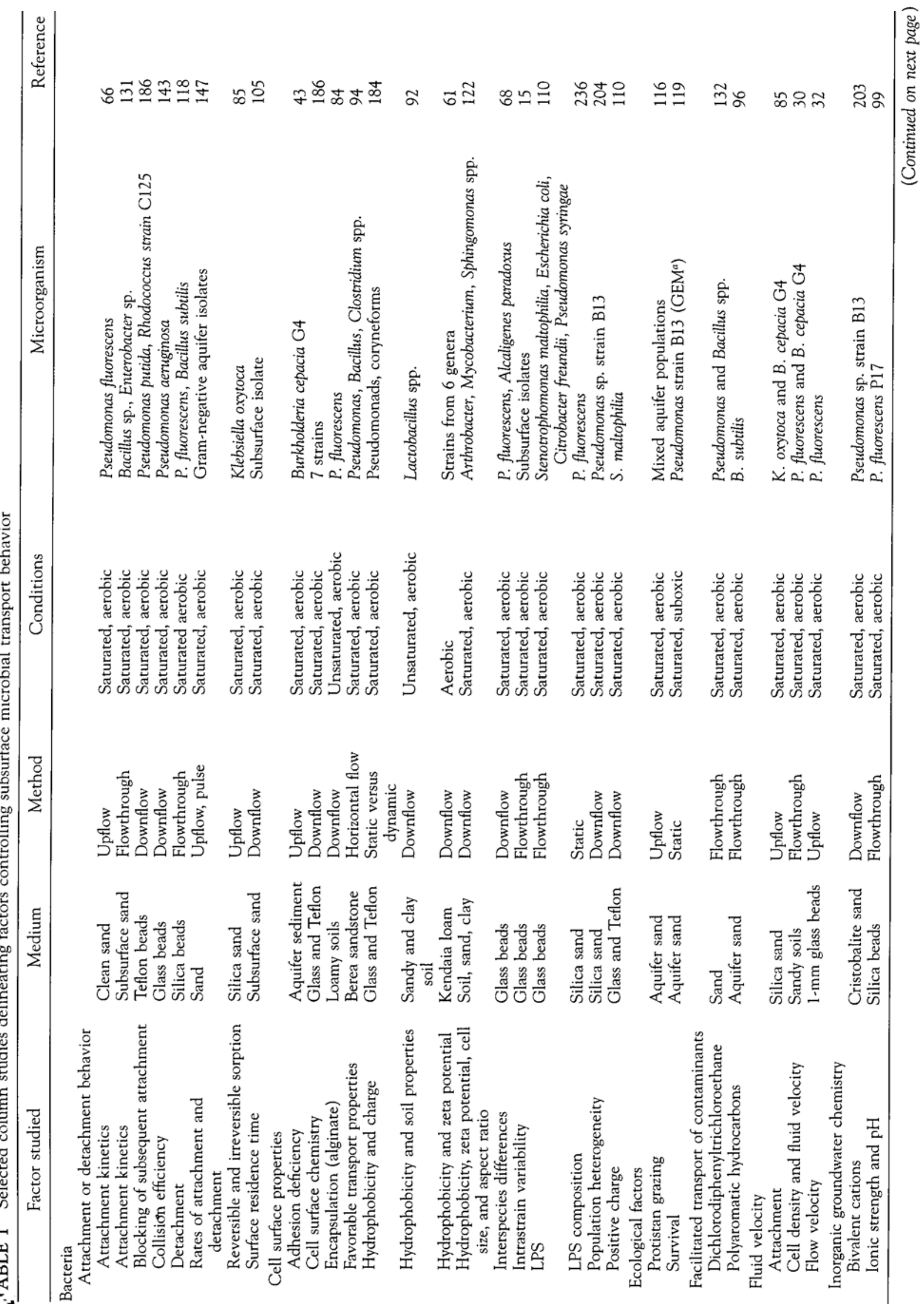




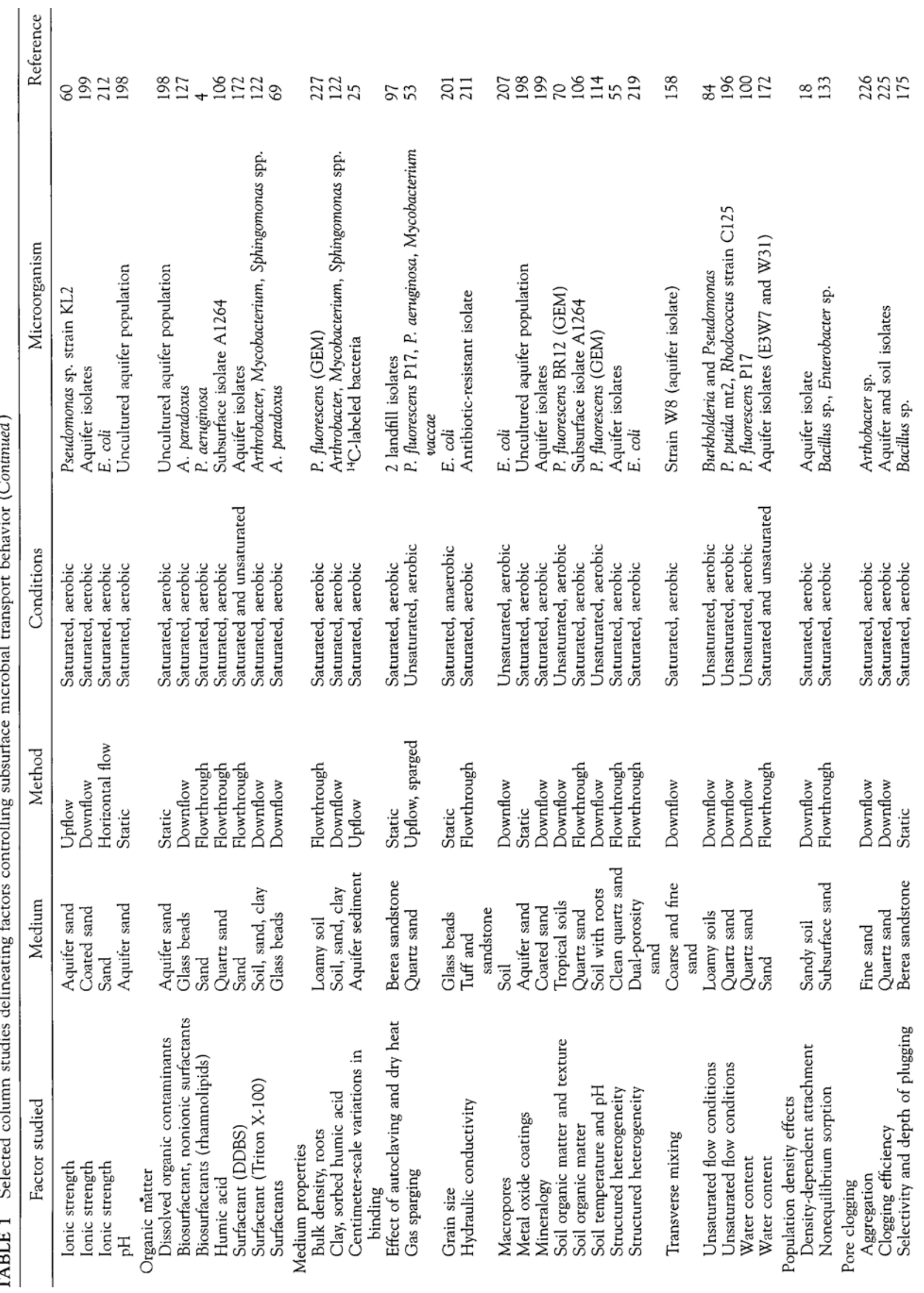




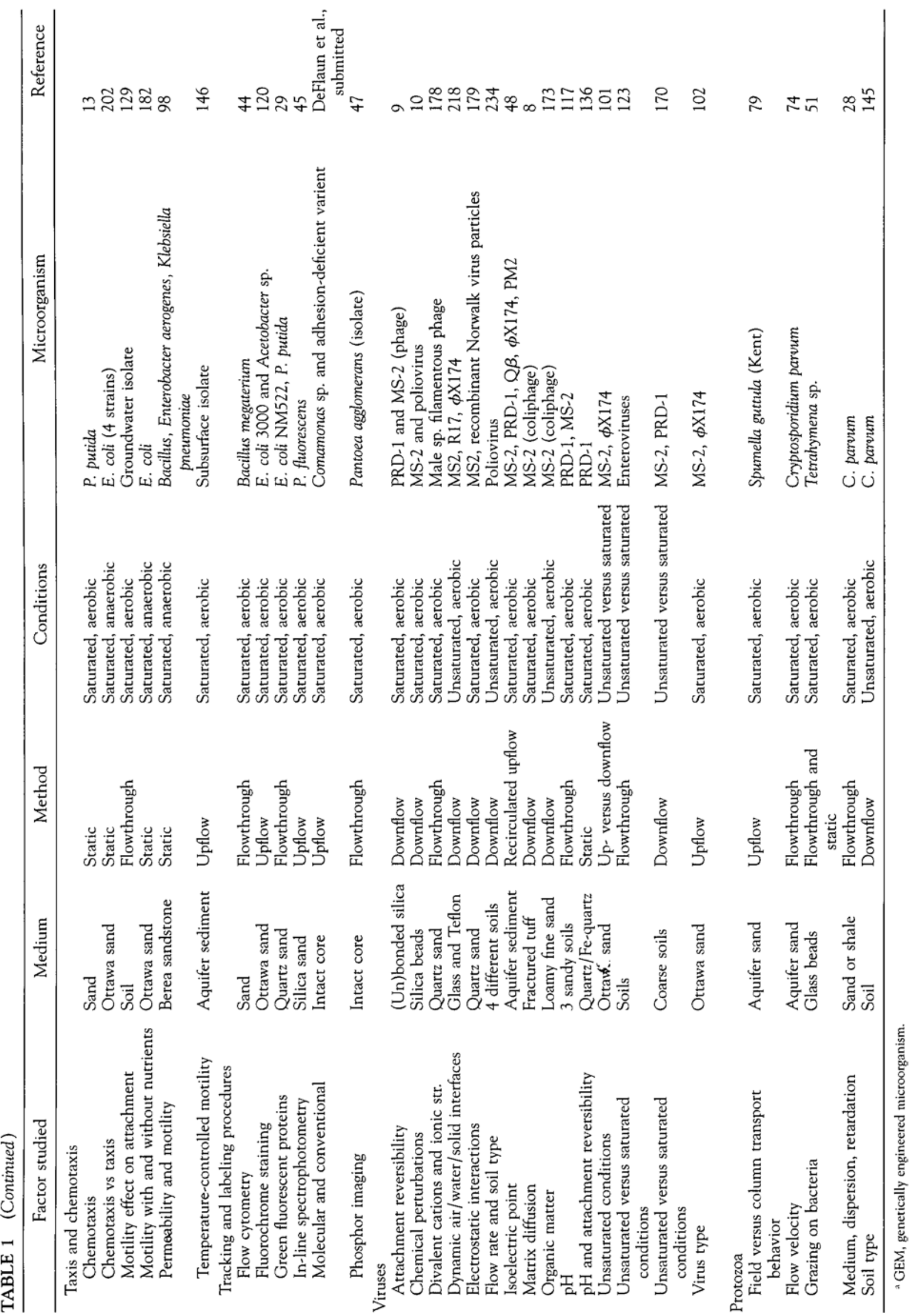


can exhibit temporal changes in transport behavior during readaptation (79).

When cultured groundwater populations are used, it is desirable to maintain in situ characteristics to the greatest extent possible. This may be facilitated by growth under conditions that mimic the environment from which the microbes were isolated. For example, it has been demonstrated that growing groundwater flagellates within porous media (sieved aquifer sediments) under nutrient and $\mathrm{pH}$ conditions similar to those of the aquifer from which they came results in cells similar in size to those found in situ (R. W. Harvey, N. Mayberry, N. E. Kinner, D. W. Metge, and G. Novarino, unpublished data). Flagellates grown in this manner exhibited different transport behavior from those grown in high-nutrient liquid media. Another method of preadapting cultured bacteria to in situ conditions is starvation prior to reintroduction (82). In a forced gradient test involving a sandy aquifer in Oyster, Va., this was accomplished by a priori suspension for $72 \mathrm{~h}$ in artificial groundwater devoid of organic carbon (42). It is also important to recognize that even the growth phase can affect the surface characteristics and attachment behavior of a bacterium in granular media. For example, it has been shown that Pseudomonas aeruginosa Olin in the stationary phase exhibits an increased $\zeta$ (zeta) potential and increased attachment to dolomite in comparison with its behavior during logarithmic growth or decay phases (66).

Using whole communities of uncultured indigenous bacteria that have been concentrated directly from the zone in which the experiment is to be run can lessen physiological changes during transport through the aquifer. Using microorganisms that are already adapted to aquifer conditions can preclude interpretation problems resulting from physiologyinduced changes in transport behavior. Bacteria may be concentrated from groundwater by dewatering techniques involving continuous-flow centrifugation or tangential-flow filtration and subsequently labeled for reinjection. An advantage of tangential-flow filtration is that the apparatus is field portable, allowing on-site concentration of aquifer microorganisms. A modified version of a commercially available microtubule-type tangential flow device (Fig. 2) was found to have a higher efficiency for concentrating bacteria from organically contaminated groundwater than did either the parallel sheet-type tangential-flow device or the continuous-flow centrifuge (121).

\section{Strain Detection}

Several flow through column studies with bacteria have employed plate count procedures for detection of unlabeled bacteria appearing in the eluent (see, e.g., references 32, 60, and 118). The advantage of plate-counting procedures is simplicity. The use of antibiotic-resistant bacteria in column experiments allows their detection on antibiotic containing media, which greatly enhances detection specificity. Other means of differential plate counts involve bacteria that produce degradation products of organic contaminants that react with a tetrazolium dye. The latter method was used for the enumeration of Methylosinus trichosporium OB3b in a methane-amended, unsaturated soil column involving vinyl chloride treatment (65). The disadvantage of plate counting is that it detects only the fraction of the total recovered population that readily grows on solid media. Also, changes in culturability during the experimental time course can hamper interpretation of plate count data.
To differentiate "test" microorganisms from indigenous subsurface populations and/or from other inadvertently introduced populations, microorganisms used in laboratory or in situ transport tests are typically labeled a priori with a stable tag. A number of field studies involving the subsurface transport of bacteria have employed DNA-specific fluorescent stains (fluorochromes)(76, 78, 80, 240). Ideally, the tags will not affect the transport behavior of the organism over the time frame of the injection and recovery experiment. Labeling the bacterial populations with the fluorochrome 4',6-diamidino-2-phenylindole (DAPI), which is known to hamper bacterial metabolism (165), retards growth and provides a long-lived (month-long) fluorescent tag in field transport studies (76). DAPI does not appear to affect bacterial attachment or transport behavior in aquifer sediments, at least over the short term $(36,120)$. However, several other fluorochromes, such as 2,7-diamino-10-ethyl-9phenyl-phenanthridinium bromide (ethidium bromide), 3,6bis(dimethylamino)acridinium chloride (acridine orange), and (2'-(4-hydroxylphenyl)-5-(4-methyl-1-piperazinyl)-2,5'bi-1-H-benzimidazole (Hoechst 33258), can affect substantively the attachment of bacteria with sand grain surfaces (120). Therefore, when using a fluorochrome to label bacteria in subsurface transport experiments, it is a good idea to ascertain its effect on cell surface properties a priori. It is still unclear what effects DAPI may have on subsurface bacterial transport in longer term, field-scale experiments. Hydroethidine, a vital eukaryotic stain (59), was used in lieu of DAPI, which is detrimental to protists, to label the nanoflagellate Spumella guttula Kent in a month-long subsurface transport study (79). More recently, a vital prokaryotic staining procedure involving 5,6-carboxyfluorescein diacetate succinimidyl ester (CFDA/SE) was developed and used in the labeling of the groundwater isolate Comamonas sp. strain DA001 for transport studies (58). It was reported that CFDA/SE labeled strain DA001 for up to 28 days without adversely affecting its physiology or transport (58).

Genetic alterations that confer considerable detection sensitivity in addition to providing a unique "marker" may be useful in identifying specific bacteria in field transport studies. To date, the testing of genetically altered bacteria was done largely at the column scale. Genetic modifications that result in the production of green fluorescent protein (GFP) have been used successfully in bacterial transport studies involving flow through columns (29). GFP, originally isolated from the jellyfish Aequorea victoria (33), has a maximum absorption of 395 and $509 \mathrm{~nm}$. GFPmodified bacteria can be detected using luminescence spectrophotometry at a detection limit of $\sim 10^{5}$ cells (29), although flow cytometry may facilitate more sensitive enumerations in the future (188). The utility of the GFP method may be enhanced by using mutant $g f p$ genes, which ameliorate several difficulties associated with the wild-type $g f p$ (e.g., low fluorescence intensity and the long delay between protein synthesis and initiation of fluorescence) (152). To track several bacterial populations concurrently, it may be possible to utilize the red-shifted GFP $(52,56)$, yellow fluorescent protein (205), or blue fluorescent protein $(112,167)$. The advantage of GFP-based identification over the below-described lux system is that the $g f p$ gene does not require additional cofactors or substrate for expression (33). However, there is a requirement for molecular oxygen, which may limit use in certain field applications. Although a single copy of $g f p$ integrated into the bacterial chromosome provides sufficient fluorescence 


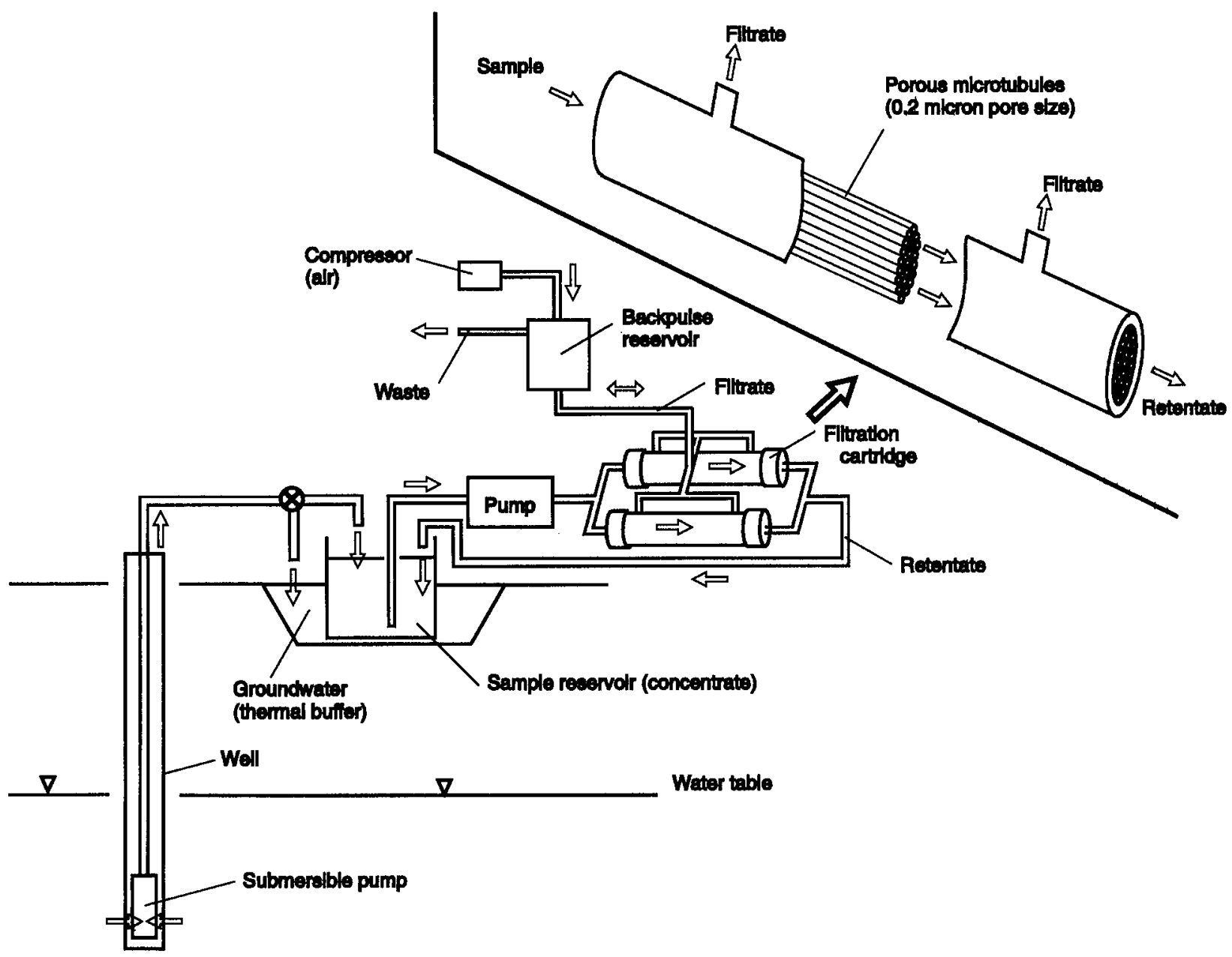

FIGURE 2 Schematic representation of a hollow-fiber type tangential-flow filtration device modified for on-site concentration of indigenous microorganisms from groundwater. Modified from reference 121 with permission of the publisher.

intensity for visualization of individual bacteria using a fluorescence microscope, fluorescence can be further enhanced by integrating two tandem copies of the $g f p$ gene (223).

lux genes also have potential for labeling bacteria of interest for subsurface transport studies in certain applications. lux $A B$ genes, encoding a bacterial luciferase, are used in the construction of "biosensor" bacteria that allow the detection and quantification of low (nanomolar) concentrations of a number of environmental contaminants (95). Luciferase-based biosensors make use of a light-emitting reaction involving the oxidation of reduced riboflavin phosphate and a fatty aldehyde to oxidized riboflavin phosphate, a fatty acid, and water (95). Because the intensity of luminescence is directly related to the energy status of a bacterium, information about relative metabolic activity may also be gathered. However, a disadvantage of using lux genes as markers in transport studies is that the light production by the bacterial luciferase is generally too weak for microscopic identification of individual bacteria. This problem can be overcome by using a dual $g f p$-luxAB marker system, which allows monitoring of the relative energy status and the total number of labeled bacterial populations in environmental samples (222). Another disadvantage is that an aldehyde substrate is required for the expression of the gene. The latter problem may be overcome by using the complete gene cassette lux CDABE (83), which encompasses the genes for aldehyde production.

The genetically conferred ability to facilitate the formation of ice in small droplets of water is yet another marker of potential interest in subsurface transport studies involving bacteria. Ice-nucleation-active (INA) bacteria, including Pseudomonas syringae, Pseudomonas fluorescens, and Erwinia herbicola, synthesize high-molecular-weight proteins in the outer membrane that function as nucleation sites for the formation of ice crystals at subzero temperatures up to $-2^{\circ} \mathrm{C}(128)$. In the absence of INA bacteria or certain very unusual steroids, water at -2 to $-5^{\circ} \mathrm{C}$ supercools and remains as a liquid. The ability of $P$. syringae to cause the freezing of $10-\mu l$ volumes of solution at around $-5^{\circ} \mathrm{C}$ formed the basis for a quick and inexpensive protocol developed by Strong-Gunderson and Palumbo (213) for using this bacterium as a tracer in a flow-through column experiment. The authors report detection limits in the range of nanograms per liter, stability over a $\mathrm{pH}$ range of 2 to 11 , and quantitative results within $3 \mathrm{~min}$ of sample collection. Therefore, INA bacteria may be useful in providing realtime information on microbial breakthrough in 
injection and recovery experiments. More recently, INA bacteria proved useful in a $36-\mathrm{m}$ microbial transport study involving fractured, highly weathered shale saprolite (150).

Other methods of labeling microorganisms for use in in situ and column transport studies have involved the use of stable-isotopes-ratio mass spectrometry (IRMS). In a smallscale, forced-gradient bacterial transport study involving a sandy aquifer in coastal Virginia, DeFlaun et al. used ${ }^{13} \mathrm{C}$ labeled bacteria at a high enough enrichment to allow quantitative detection in groundwater samples collected downgradient of the injection (42). Advantages of using ${ }^{13} \mathrm{C}$ to label microorganisms in in situ transport experiments include its benign effect on both the microorganisms of interest and the investigators, although the relatively high cost of stableisotope analysis may impose a practical limit on the scale of the experiment.

Radiolabeling has been used in a number of laboratory studies involving transport of bacteria (see, e.g., references $25,30,47,68,69,100,133)$ and viruses $(136,179)$ in porous media. However, the potential hazards involving field applications of radioisotopes in microbial transport studies may restrict their use to studies involving short-lived isotopes and controlled-access sites. ${ }^{32} \mathrm{P}$, which has a half-life of only 14 days, has been used to label Escherichia coli and the bacteriophage PRD1 in injection and recovery experiments on the property of the Chalk River Nuclear Laboratories (Chalk River, Ontario, Canada) (34) and at the U.S. Geological Survey large-scale tracer array in Falmouth, Mass. (169, 193), respectively. The advantages of using radioisotopes include a minimal effect on cell metabolism, a high sensitivity, and a relatively low cost of analysis. Radioisotope labeling is particularly useful for in situ phage transport studies because, unlike the standard plaque counting procedures designed to quantify the infective phage, it allows determinations of the total numbers of phage transported. Use of different radiolabels for the protein-containing virus capsid and the enclosed genetic material allows the investigator to assess the structural integrity of the virus during the test (160). This is because the ratio of the two isotopes, after correcting for radioactive decay, should change after disintegration of the virus because the protein-containing capsid and the DNA or RNA will have different propensities for attachment to grain surfaces.

Because of its high specificity for detecting specific organisms, the use of PCR can alleviate the need for a priori labeling altogether. Because probes and primers are available for the $5^{\prime}$ noncoding region common to many viruses, PCR has been particularly useful for detection of enteroviruses in both groundwater (2) and subsurface soil (212) to assess their extent of subsurface transport. The major advantages of PCR are that it detects only intact nucleic acid sequences and that it can detect enteroviruses that have lost their ability to replicate in cell cultures. Disadvantages of using PCR to assess transport of specific enteroviruses in in situ injection and recovery tests include its inability to distinguish between infective and noninfective viruses and its relatively high cost. Also, it is only semiquantitative and cannot provide the kind of high-precision data required in many modeling applications. Recently, bacteriophage M13mp18 was genetically modified to enhance its suitability as a tracer at a restricted field site. The genome contained a unique identification sequence that could be identified by a number of techniques, including PCR (41). Construction of an $E$. coli strain that expresses a stable artificial RNA from the chromosomal $r r n \mathrm{H}$ operon may be useful for in situ microbial transport experiments because the large number of stable artificial RNA products per cell enhances signal detection (6).

DeFlaun et al. (M. F DeFlaun, M. E. Fuller, P. Zhang, W P. Johnson, B. J. Mailloux, W E. Holben, W P. Kovacik, D. L. Balkwill, and T C. Onstott, submitted for publication) describe a study in which a number of the aforementioned methods for tracking specific bacteria were applied to an intact-core experiment. These authors compared resulting breakthrough data for seven techniques of tracking bacteria in transport studies involving subsurface materials, i.e., direct counts of fluorescently stained bacteria (78), plate counts, microplate spectrofluorometric (58) and flowcytometric $(44,221)$ enumerations, ferrographic tracking (107, 243, 244), IRMS of ${ }^{13} \mathrm{C}$-labeled bacteria (88), and quantitative PCR (W P. Kovacik and W E. Holben, submitted for publication). The authors report good correlations between the effluent concentration histories for each of the last six methods and the direct counting procedure. However, the reported limit of detection varied considerably and ranged from 2 cells/ml for IRMS to $3 \times 10^{5}$ cells $/ \mathrm{ml}$ for the microplate spectrofluorometric method. The per-sample costs were reported to vary by at least a factor of 10 among the different methods (DeFlaun et al., submitted). Therefore, the choice of methods for tracking bacteria in transport experiments may depend on a number of factors including the cost, the availability of required instrumentation, and the required precision of measurement. For laboratory-scale experiments, the minimum sample volume required for analysis may be an important consideration. For example, the $50 \mathrm{ml}$ of sample required for ${ }^{13} \mathrm{C}$-IRMS (DeFlaun et al., submitted) may preclude its use in many column studies.

\section{Physical and Population Heterogeneities}

For bacteria, chemical and physical heterogeneity in the aquifer collectively affect most of the factors that influence the extent of travel in the aquifer (75). Even in relatively homogeneous aquifer sediments composed of well-sorted sand, physical (e.g., grain size distribution) and geochemical (e.g., mineralogical) heterogeneities cause apparent changes in microbial transport behavior. In an injection and recovery experiment in which a labeled indigenous bacterial population, a conservative tracer (bromide), and a particulate tracer (bacteria-sized microspheres) were coinjected into adjacent layers of a relatively homogeneous sandy aquifer, the relative order of appearance of peak abundance of the three constituents varied from layer to layer $(80)$. Substantive changes in the rates of immobilization, retardation, and apparent dispersion over short distances in the aquifer require verification that a given observed transport behavior is not an artifact of system heterogeneities.

Accurate modeling of microbial transport in granular aquifers over environmentally significant distances may necessitate both a detailed knowledge of the spatial variability in physical aquifer properties and a model that takes that into account. A stochastic model that employed sitespecific physical variability information gathered in earlier hydrologic studies $(62,124)$ was used to simulate viral transport over a 36-m transect in a sandy aquifer (180). The model simulations suggest that physical heterogeneity (expressed as the variance in the natural log of hydraulic conductivity, $\ln K$ ) may be a major determinant of microbial transport over environmentally relevant distances. Indeed, very little viral transport was predicted in the absence of physical heterogeneity. Although stochastic models de- 
scribing subsurface microbial transport have yet to be validated with large-scale, three-dimensional data sets, an excellent correlation between In $K$ and the collision efficiency factor $(\alpha)$ was demonstrated for microbe-sized colloids in flow-through columns of granular media (181).

Assessment of the spatial variability of $\ln K$ for the purposes of subsurface microbial transport modeling requires that many labor-intensive measurements be made in the aquifer or on core samples taken from the aquifer. Relatively homogeneous aquifers may be characterized by $K$ values that vary by an order of magnitude (86), whereas heterogeneous aquifers are characterized by $K$ that vary by several orders of magnitude. There are many ways to estimate hydraulic conductivity variations within granular aquifers, including permeameter assays on intact aquifer sediment cores and borehole flow meter tests (see, e.g., reference 86), as well as estimates from tracer or pump tests using existing well networks $(137,215,245)$ and from measured sediment parameters, i.e., grain size distribution, the fractal dimension and entropy of the distributions, porosity, soil density, and fines content (23). Although the various methods can yield different values of $K(156)$, the spatial variability of $K$ is the more critical parameter in accounting for subsurface microbial transport on the scale of tens or hundreds of meters using stochastic models. Noninvasive geophysical techniques (e.g., ground-penetrating radar) (19, $20,90)$ for estimating physical variability within granular aquifers are gaining popularity. This is largely because the methods are nondestructive and more readily yield threedimensional information about the geometry of inhomogeneities than would be possible using core analyses or pump tests.

Another important heterogeneity that can lead to higherthan-predicted subsurface transport of microorganisms involves intrapopulation variabilities in adhesive properties. Since the first report suggesting the existence of two subpopulations for the same bacterial strain, each possessing distinctly different adhesive properties (200), a number of studies have suggested that intrastrain variations in bacterial surface properties $(4,15,63,204)$ can lead to differences in attachment behavior. Therefore, when using a cultured bacterium in an in situ transport study, it may be useful to ascertain whether bacteria collected in the effluent of a short (several centimeters) flow-through column of saturated, well-defined porous media exhibit a different average collision efficiency when passed through a second identical column (204).

\section{IN SITU STUDIES}

\section{Tracers}

Recent in situ investigations designed to examine microbial transport behavior in groundwater have involved the coinjection into the aquifer of the microorganism of interest with a conservative solute tracer (usually chloride, bromide, or iodide). Conservative tracers (nonreactive solutes) are typically used to monitor the velocity and direction or path of groundwater flow and the degree of dispersion (spreading of the injectate that is caused by diffusion and by mixing with adjacent parcels of water). Dimensionless concentration histories (breakthrough curves) of the conservative tracers are then obtained for sampling points that are downgradient and in the path of the injectate cloud. The characteristics of the conservative-tracer breakthrough curve can then be used comparatively to determine some of the major transport parameters exhibited by the introduced microorganisms. When using halide tracers, it may be necessary to consider their effects on microbial activity (67) and on the density of the injectate cloud (124). For many small-scale injection and recovery experiments, halide concentrations in the 100 - to $200-\mathrm{mg} \bullet 1^{-1}$ range are sufficient. For small-scale field studies involving a pulse (slug) input, conservative-tracer transport data may be used to help calculate microbial transport parameters as described below.

Retardation of the microbe $(\mathrm{R})$, which is caused by reversible interactions with stationary surfaces, can be determined by comparing the velocities of the peak concentration of conservative tracer and the introduced microorganism at sampling points downgradient from point of injection:

$$
R=V_{\text {tracer }} / V_{\text {micruhe }}
$$

where $V_{\text {tracer }}$ and $V_{\text {microbe }}$ are the observed average velocities of the peak concentrations of the tracer and the microorganism, respectively, that appear at a downgradient well. For cases where the breakthrough curves for the microorganism and conservative tracer are dissimilar in shape or where the curves are multipeaked, retardation may be approximated as the ratio of the times required for the arrival of the centers of mass (estimated by numerical integration) of the introduced microorganism and the conservative tracer (79).

Theoretically, dispersivities of conservative solutes and microorganisms should be similar because dispersivity is a physical property of a porous medium (27) that determines the degree of mixing with adjacent parcels of groundwater along the flow path. However, the apparent longitudinal (direction of flow) dispersion exhibited by the microorganism in granular aquifers will usually be greater than that of the conservative tracer, because reversible interactions with grain surfaces differentially retard portions of the microbial population relative to the conservative tracer. On the other hand, a high degree of preferential flow path structure in some granular aquifers can result in a greater apparent dispersion for the conservative tracer than for the microorganism (see, e.g., reference 164). This is because microbial transport in the later, more heterogeneous systems can be limited to the larger pores, resulting in a breakthrough pattern that is less skewed than the conservative tracer. Apparent longitudinal dispersion $\left(a_{\mathrm{L}}\right)$ for the microorganisms is sometimes estimated using a simplified one-dimensional approach (76):

$$
\mathbb{a}_{L}=\frac{\chi_{1}\left(\Delta t / t_{\text {peak }}\right)^{2}}{16 \ln 2}
$$

where $x_{1}$ is the distance from point of injection, $\Delta_{t}$ is the duration of breakthrough when $\mathrm{C}(t)>$ half the peak concentration, and $t_{\text {peak }}$ is the time required to reach the peak concentration. In many cases, such calculated values are only first approximations. This is because the concentration histories of the microorganisms often do not conform to the assumed classical Gaussian-shaped breakthrough curves on which the above equation is based. The above equation may not be suitable for calculating apparent dispersion for microorganisms exhibiting highly irregular, multipeaked breakthrough curves. Apparent longitudinal dispersion may also be calculated from three-dimensional breakthrough curves by using the standardized first and second moments of the spatial distributions (64). The inter- 
ested reader is referred to reference 164 for a detailed explanation of the method of using the moments approach for determining apparent dispersivities for microorganisms in injection and recovery studies that employ a threedimensional sampling array.

In granular aquifers, differences between the conservative-tracer and microbial breakthrough curves are due largely to the interactions between the microorganisms and the grain surfaces. The simplest method of accounting for microbial attachment to surfaces is to assume that the microbial distribution between solution and solid surface is constant. This approach assumes that attachment is always at equilibrium and therefore that the solid/solution partitioning of the microorganisms can be described by a single coefficient of distribution $\left(K_{\mathrm{d}}\right)$. However, judging from the protracted nature of the trailing ends of microbial breakthrough curves relative to those of the conservative tracer in most field tests (Fig. 3A), an equilibrium assumption usually is not appropriate. A better approach involves consideration of the attachment and the detachment kinetics of microorganisms being advected (carried along by fluid flow) downgradient (133). Aquifer sediments are characterized by many different types of attachment sites. However, it can be useful for modeling purposes to assume that
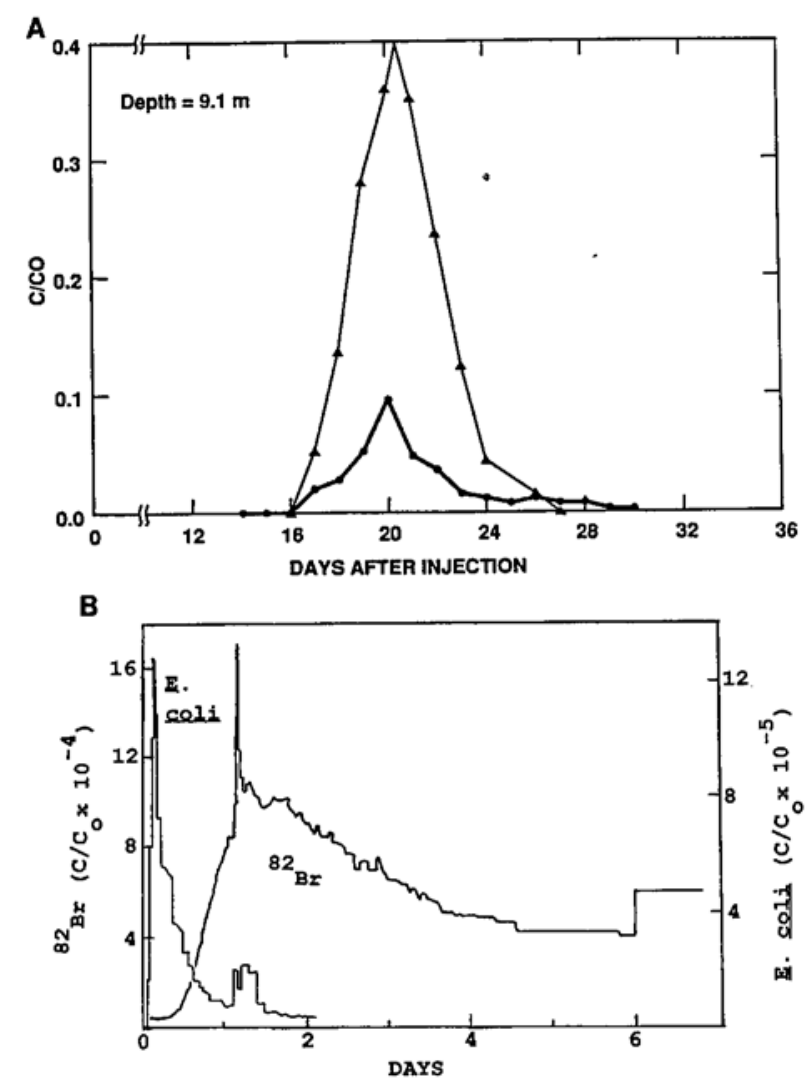

FIGURE 3 Dimensionless concentration histories for bacteria and bromide transported downgradient through aquifers from the point of coinjection. (A) Natural-gradient test in a wellsorted, sandy aquifer in Cape Cod, Mass. Reprinted from reference 21 with permission of the publisher. (B) Forcedgradient test in a fractured, granite aquifer at Chalk River Laboratory, Ontario, Canada. Redrawn from reference 34 with permission of the publisher. there are two types of attachment sites. Specifically, it can be assumed that one type of site is responsible for permanent microbial immobilization and one type is responsible for reversible microbial attachment (76). The former type results in attenuation of the height of the microorganism breakthrough curve (plotted as dimensionless concentration history versus time) relative to that of the conservative tracer. The latter (weaker) type results in retardation of the center of mass of the micro-organisms reaching the downgradient sampling point.

The fraction of microorganisms injected into the aquifer that become irreversibly attached (within the experimental time frame) during transport to a downgradient sampler may be calculated from its relative breakthrough $(\mathrm{RB})$. The $\mathrm{RB}$ is determined by comparing the numerical integration of the dimensionless concentration history of the microbe to that of the conservative tracer (78):

$$
\mathrm{RB}=\int_{t_{0}}^{t_{f}} \frac{\mathrm{C}(t)}{\mathrm{C}_{0}} d t \div \int_{t_{0}}^{t_{f}} \frac{\operatorname{Tr}(t)}{\mathrm{Tr} r_{0}} d t
$$

where $C_{\mathrm{o}}$ and $T r_{\mathrm{o}}$ are the respective microorganism and conservative tracer concentrations in the injectate, $C(t)$ and $\operatorname{Tr}(t)$ are concentrations downgradient at time $t, t_{\mathrm{o}}$ is the time of injection, and $t_{\mathrm{f}}$ is the elapsed time from the beginning of injection until the termination of breakthrough. The abovedescribed integrals, in most cases, may be reasonably estimated by simple numerical integration.

The RB may, in turn, be used to estimate the collision efficiency factor. The collision efficiency factor, $\alpha$, is a parameter in filtration theory that represents the physicochemical factors that determine irreversible microbial immobileization (76):

$$
\alpha=\frac{\left.d\left[1-2\left(\mathrm{ce}_{\mathrm{L}} / x_{1}\right) \ln (\mathrm{RB})\right]^{2}-1\right\}}{6(1-\theta) \eta\left(\mathrm{d}_{\mathrm{L}}\right.}
$$

where $d$ is the grain size in centimeters, $\mathrm{x}_{1}$ is the travel distance from point of injection to the sampler at which the concentration history was monitored, $\theta$ is the porosity, and $\eta$ is the single-collector efficiency. Most often, the median grain diameter is used for $d$. However, it should be noted that characteristic diameters based on the smaller grains, e.g., upon the arithmetic average, geometric mean, or the $d_{10}$ (diameter at which $10 \%$ of the grains are smaller), have been reported to yield results that more accurately described bacterial transport in the different-sized porous media (140). The latter parameter $(\eta)$ is the rate at which the microorganisms strike a single sand grain divided by the rate at which they move toward the grain and represents the physical factors determining collision. Two clean-bed filtration models are commonly used to describe the contact of microorganisms with stationary surfaces in granular media. Simply put, the two models differ in how $\eta$ is calculated. The older model of Yao et at. (241) considers three types of mechanisms by which microorganisms contact the surface, i.e., Brownian motion, physical interception, and settling. The model described by Rajagopalan and Tien (176) includes the aforementioned mechanisms but also includes close-approach effects. The latter model has been most commonly used in the recent literature. However, the original paper describing the latter model contains several errors, which were clarified by Logan et al. (134, 135). Using the model of Rajagopalan and Tien (176), the value of $\eta$ may be calculated as follows: 


$$
\begin{aligned}
\eta= & 0.72 \mathrm{~A}_{\mathrm{s}} N_{\mathrm{L}}^{1 / 8} N_{\mathrm{R}}^{15 / 8}+2.4 \\
& \times 10^{-3} \mathrm{~A}_{\mathrm{s}} N_{\mathrm{G}}^{1.2} N_{\mathrm{R}}^{-0.4}+4 \mathrm{~A}_{\mathrm{s}}^{1 / 3} N_{\mathrm{Pe}}^{-2 / 3}
\end{aligned}
$$

where $\mathrm{A}_{\mathrm{s}}=2\left(1-\mathrm{p}^{\mathrm{j}}\right) / w ; w=2-3 \mathrm{p}+3 \mathrm{p}^{3}-2 \mathrm{p}^{\mathrm{o}} ; \mathrm{p}=(1-$ $\theta)^{1 / 3} ; \mathrm{N}_{\mathrm{Lo}}=\mathrm{H} / 9 \pi \mu \mathrm{a}_{\mathrm{p}}{ }^{2} \mathrm{U} ; \mathrm{N}_{\mathrm{R}}=\mathrm{a}_{\mathrm{p}} / \mathrm{a}_{\mathrm{s}} ; \mathrm{N}_{\mathrm{G}}=2 \mathrm{a}_{\mathrm{p}}{ }^{2}\left(\rho_{\mathrm{p}}-\rho\right) g / 9 \mu \mathrm{U} ;$ and $\mathrm{N}_{\mathrm{Pe}}=48 \pi \mu \mathrm{a}_{\mathrm{s}} \mathrm{a}_{\mathrm{p}} \mathrm{U} / k \mathrm{~T}$. In the above expression, $\mathrm{a}_{\mathrm{p}}$ and $\mathrm{a}_{\mathrm{s}}$ are the respective colloid and grain radii, $\mu$ is the fluid viscosity, $\mathrm{U}$ is the velocity of the groundwater, $\theta$ is the porosity, $\rho$ and $\rho_{p}$ are the respective densities of the groundwater and the microorganism, $g$ is the acceleration due to gravity, $\mathrm{T}$ is temperature (in Kelvin), $k$ is Boltzmann's constant $\left(1.38 \times 10^{-23} \mathrm{~J} / \mathrm{mol} \cdot \mathrm{K}\right)$, and $\mathrm{H}$ is the Hamaker constant. The value of the Hamaker constant depends on the particular system under study. For bacteria sorbing onto glass or quartz surfaces at room temperature, an approximate value of $10^{-20} \mathrm{~J}$ is used (e.g., see reference 127).

Reversible types of attachment result in an increased travel time and apparent dispersion for the microorganisms relative to the conservative tracer. Although there is experimental evidence for the removal mechanisms (generally assumed irreversible) described by filtration theory (above), there is also evidence that nonequilibrium reversible attachment is a common feature of microbial transport in aquifers (76). The nonequilibrium is caused by a rate of attachment different from the rate of detachment and can be accounted for by using different attachment and detachment rate constants in modified advection-dispersion models describing microbial transport in porous media. The development of specific models for describing microbial transport through aquifer material is beyond the scope of this chapter. The interested reader is referred to references 115 and 131 for discussions of kinetic modeling of microbial transport through saturated granular media, to reference 76 for a discussion of how filtration theory and mathematical descriptions of reversible attachment can be coupled with a hydrologic transport (advection-dispersion) model to describe small-scale field results, to reference 180 for a description of a stochastic (probabilistic) model describing viral transport on a substantive field scale, to reference 170 for a comparison of models with kinetic and equilibrium adsorption, to reference 126 for discussions of how to model a number of bacterial transport processes in heterogeneous porous media, including cell diffusion, aggregation, localization of microbial growth sites, and long-term survival, to reference 89 for an evaluation of a model using laboratory data, to reference 159 for an overview of current approaches used to represent physicochemical and biological process in porous media, to reference 214 for a description of modeling of microbial transport in dual porosity media, to reference 50 for a description of how random-walk calculations can be used to describe bacterial migration in porous media, to reference 217 for a discussion of biomass transport in the presence of utilizable substrate, and to reference 91 for discussions of subsurface microbial fate and transport models.

In addition to providing a framework within which the transport behavior of microorganisms can be evaluated, conservative tracers can be useful for supplying information about movement of the injectate cloud within sampling arrays. This information facilitates a sampling protocol that will allow the capture of most of the microbial breakthrough. However, the usefulness of conservative tracers in this regard depends on the type of aquifer in which the experiment is run. For homogeneous zones of sandy aquifers, dimensionless concentration histories of the conser- vative tracer can be similar to those of the bacteria or viruses coinjected with it (Fig. 3A) (11, 76). In general, physical heterogeneity of the system increases the dissimilarity between the breakthrough curves of the conservative tracer and the microorganisms $(55,76,80)$. For aquifers characterized by fracture-flow, arrival of peak microbial concentration at a downgradient sampling point can greatly precede that of the conservative tracer (Fig. 313). This is because the microorganisms are largely confined to the major flow paths (fractures) and therefore are subject to an average travel path much shorter than that of the conservative tracer. In extreme cases, microbial breakthrough at downgradient sampling points terminates before arrival of measurable tracer concentrations. Because the pore volumes available for transport of microorganisms and solutes can be quite different in highly fractured aquifers, conservative tracers are less useful in providing real-time information about how and where to sample and in providing a comparative reference for determining microbial transport parameters.

The degrees of similarity between the microbial and solute tracer breakthrough curves are also influenced by the size and surface chemistry of the microorganism being evaluated. For example, substantial retardation of aquifer flagellates (protozoa) relative to bromide was observed for transport in a well-sorted, sandy aquifer where retardation of indigenous bacteria is generally not observed (79). Earlier tests with different sizes (diameter, 0.23 to $1.35 \mu \mathrm{m}$ ) and types of microspheres revealed that the reactivity of the surface was a much stronger determinant of retardation than the size (78).

Microspheres have been useful as particulate tracers to study the effect of cell size and surface characteristics on microbial transport behavior in sandy aquifer sediments because they are physically and chemically well defined. Microspheres also can serve as tracers for contamination of subsurface core material by nonindigenous bacteria (see chapter 64) (37). However, the transport properties of microspheres in porous media can differ from those of microorganisms. For example, it has been shown that the degrees of retardation, apparent dispersion, and immobilization exhibited by various types of commercially available microspheres differ from those exhibited by bacteria (78). On the other hand, 2- $\mu \mathrm{m}$-diameter carboxylated microspheres exhibit similar transport properties to groundwater flagellates (protozoa) in an injection and recovery experiment performed in a sand and gravel aquifer (79). Fluorescent microspheres are easy to detect and, in groundwater samples with low turbidity, can be enumerated efficiently by using either computer-coupled image analysis or flow cytometry (16). The latter method may be adapted for online enumeration of microspheres in flow-through columns of porous media (161) or for enumeration of microspheres in field tracer tests (114a, 162).

\section{Natural- and Forced-Gradient Tracer Tests}

Several different types of injection and recovery tests have been used to investigate microbial transport in situ (Fig. 4). Forced-gradient tests are ones in which the flow field is controlled by high-volume pumping at the point of injection, the point of withdrawal, or both. Forced-gradient tests have the advantage of substantially shortening the time frame required to obtain complete breakthrough of the injected constituents. They have been used in granular aquifers to study the transport behavior of bacteria $(42,78)$, viruses (12), and yeasts (239). However, this type of 
A.

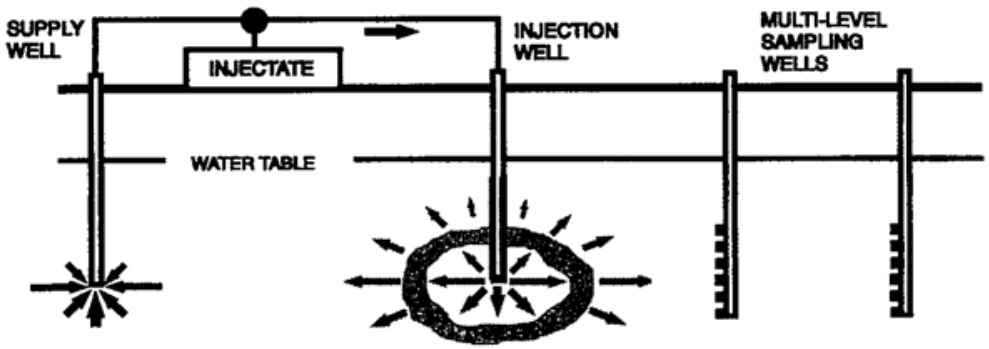

B.

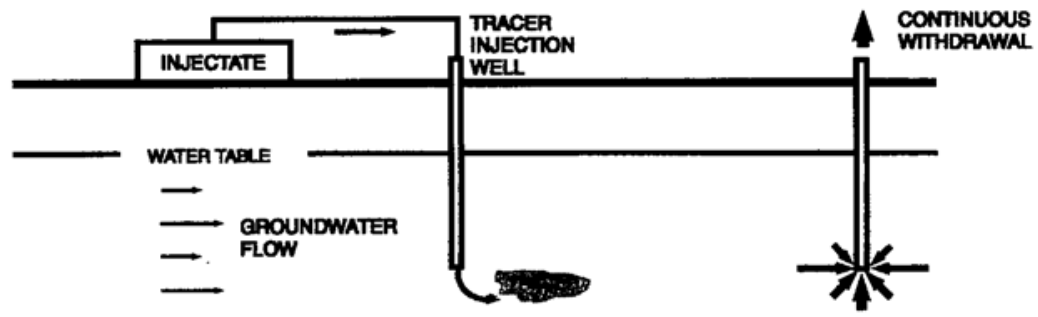

C.

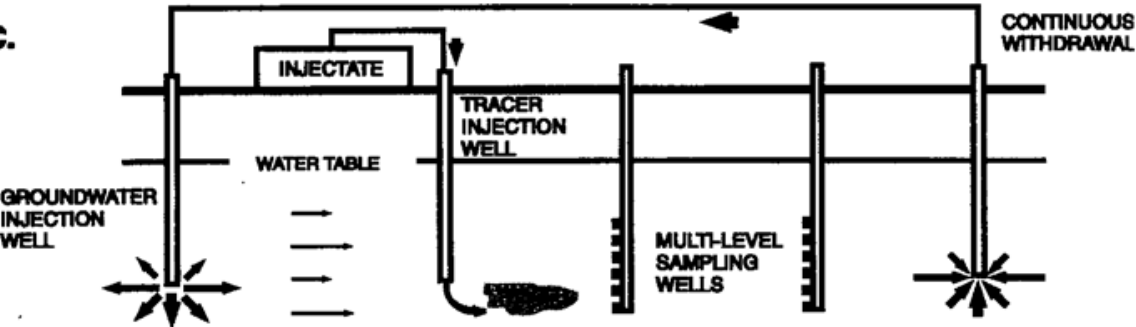

D.

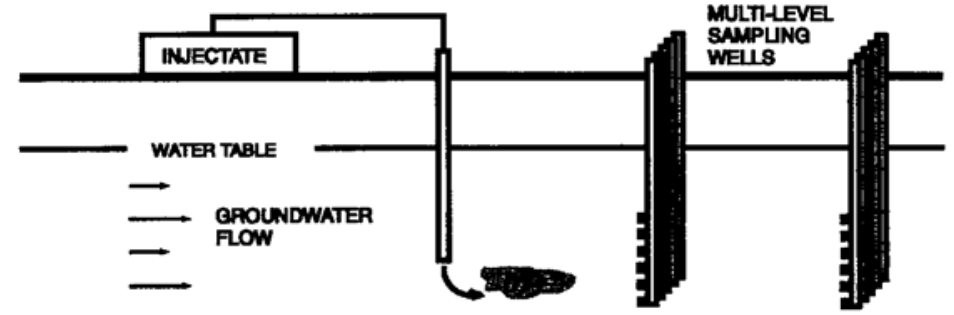

FIGURE 4 Schematic depiction of experimental designs for small- to intermediate-scale injection and recovery investigations examining microbial transport behavior in aquifers. (A) Divergent, forced-gradient test. (B) Convergent, forced-gradient test. (C) Doublet cell, forced-gradient test. (D) Natural-gradient test. Modified from reference 21 with permission of the publisher.

test is particularly well suited for microbial transport studies in aquifers characterized by fracture-flow, because the sampling wells do not have to be placed immediately downgradient. Forced-gradient tests have also been used in aquifers characterized by fractured clay and crystalline rock to study the transport behavior of viruses (149) and bacteria (34). A disadvantage of forced-gradient tests is that the flow field is nonuniform and therefore more difficult to model.

Divergent-tracer tests involve a quick addition of a known quantity of microorganisms and conservative tracer to a continuous stream of groundwater being injected back into the aquifer. This setup produces radially divergent flow and forces the gradient in all directions (Fig. 4A). Because of the high degree of forced dispersion, the distance over which the injectate can be monitored is limited. A convergent test can be performed by continuous withdrawal at the sampling well (Fig. 4B). The advantage of the convergent test is that, theoretically, the entire mass of conservative tracer is recovered at the sampling well. This makes it possible to do a true mass balance on both the conservative tracer and the microorganisms. A variation of the simple convergent test is the doublet cell (Fig. 4C), in which an injection is made within the flow field created 
by a coupled continuous groundwater injection and withdrawal. The result is a flow field that can be controlled over moderate distances. The latter method is particularly useful for simulating conditions that may result during engineered remediation of contaminated aquifers.

In natural-gradient tests (Fig. 4D), the injectate is added slowly to the aquifer and the natural flow of groundwater advects the injectate cloud past rows of multilevel samplers (MLS) placed in rows perpendicular to the flow path. Natural-gradient tests are best suited for sandy aquifers, where the flow direction can be predicted within reasonable limits and where the water table is shallow enough to permit the use of peristaltic pumps to sample water from each level of the MLS. The construction and use of MLS are discussed by Pickens et al. (168) and Smith et al. (208). For small-scale experiments, the individual MLS within the downgradient rows should be as close as possible. As a practical working-limit, MLS installed using hollow-stem auger drill rigs (see chapter 64) cannot be placed much closer than I in.

Transport tests can also be designed using a non-point-source addition and sampling points that line along a transect parallel to the longitudinal axis of the source at some fixed distance downgradient. A non-point-source design was used to assess the efficacy of artificial recharge to remove MS2 and PRD1 bacteriophages added to an elongated recharge basin in Castricum, The Netherlands. A trench- to-trench bacteriophage (MS2 and PRD1) transport experiment, also involving MS2 and PRD1, was conducted in weathered, fractured clay till in Ontario, Canada (149). Both field-scale experiments were facilitated by low groundwater temperatures $\left(7\right.$ and $10^{\prime} \mathrm{C}$, respectively), which greatly diminished temperature-dependent virus inactivation. An advantage of this type of test is that transport behavior over several parallel flow paths of similar distance is observed and information about the effects of field-scale heterogeneity on microbial transport can be gathered (197).

The quantity of microorganisms needed to conduct an injection and recovery experiment depends on the type of injection test to be run, travel distance, type of microorganism (and associated minimum level of detection), and aquifer characteristics. In general, the divergent- tracer (Fig. 4A) test will require the largest number of microorganisms. The radially divergent flow field in this type of test results in decreases in microbial concentration that are proportional to the square of the travel distance. This is, of course, in addition to losses from solution due to immobilization at solid surfaces. Natural-gradient experiments (Fig. 4D) often require the smallest number of microorganisms. This is because of the absence of forced dispersion caused by forced-gradient conditions and/or of large dilution factors at the point of collection. If the physical parameters (flow direction, velocity, dispersivities, porosity, grain size distribution, and injection and sampling point coordinates) are known and the aquifer is relatively homogeneous, a rough estimate of the number of microorganisms required for the test may be obtained by first calculating the degree of dilution that would occur along the experimental flow path as a result of dispersion and then applying a filtration factor.

The degree of dilution due to dispersion or to sampling at some distance from the travel path taken by the center of injectate mass may be roughly estimated by

$$
\begin{aligned}
& C_{(x, y, z, t)}=\left(\frac{C_{0} V_{0}}{8 \theta(\pi t)^{3 / 2}\left(D_{x} D_{y} D_{x}\right)^{1 / 2}}\right) \\
& \quad \exp \left(-\frac{(x-v t)^{2}}{4 D_{x} t}-\frac{y^{2}}{4 D_{y} t}-\frac{z^{2}}{4 D_{z} t}\right)
\end{aligned}
$$

where $\mathrm{C}$ is the concentration at time $\mathrm{t} ; \mathrm{C}$, and $\mathrm{V}$, are the respective initial (injectate) concentration and volume; $\mathrm{a}$ is the porosity; $\mathrm{x}$ is the distance in the direction of flow; $y$ is the distance in the horizontal transverse direction; $\mathrm{z}$ is the distance in the vertical transverse direction; $\mathrm{D}, \mathrm{D}$, and $\mathrm{D}$, are the coefficients of dispersion in the $\mathrm{x}, \mathrm{y}$, and $\mathrm{z}$ directions, respectively; and $\mathrm{v}$ is the flow velocity. This expression is a modified solution of the well-known advection-dispersion equation (57), i.e.,

$$
\frac{\delta \mathrm{C}}{\delta t}=-v \frac{\delta \mathrm{C}}{\delta x}+D_{x} \frac{\delta^{2} \mathrm{C}}{\delta x^{2}}+D_{y} \frac{\delta^{2} \mathrm{C}}{\delta y^{2}}+D_{z} \frac{\delta^{2} \mathrm{C}}{\delta z^{2}}
$$

Because local heterogeneities can substantively affect the values of the above-listed aquifer properties, it is almost always preferable to run an initial test with conservative tracers (as described in the preceding section). The resulting information on the flow direction and dispersivities in the test zone can be used to adjust the required volume of a subsequent coinjection involving microorganisms and tracers. Increasing the volume of the injectate results in both a decreased dispersion effect and a larger injectate cloud. The latter can often compensate for downgradient sampling points that do not lie along the trajectory taken by the center of mass.

The degree of immobilization experienced by microorganisms as they travel along the experimental flow path is difficult to estimate without a priori information derived from earlier in situ tests or from flow-through column experiments. For bacteria, the loss of organisms due to interaction with grain surfaces in sandy aquifer sediments can be at least I log unit per 10 in of travel (76). Consequently, for small-scale (: ; Io in) natural-gradient injection and recovery tests, a minimum fluorescently stained bacterial population of 106 to 107 . MI-I suspended in an injectate volume of 100 to 200 liters $(76,78)$ would be required to obtain an accurate concentration history at the downgradient samplers by using an epifluorescence direct-counting procedure (e.g., see reference 87). The level of detection, which is an important determinant of the required number of labeled bacteria in the injectate, is controlled largely by the quantity of suspended particulate matter in the groundwater. This is because the number of suspended particulates determines the volume that may be filtered for the direct enumeration procedure. For viruses, a loss of at least I log unit over the first $I$ in of travel is often observed $(12,169)$. Schijven et al. (197) reported a 3-log-unit decline in bacteriophage within the first 2.4 in of travel through sandy aquifer sediment. However, for some heterogeneous aquifers characterized by high groundwater velocities, <1-log unit declines in phage over travel distances of many meters have been documented (114b, 190).

\section{LABORATORY STUDIES}

\section{Flow-through Columns}

Packing of large columns with subsurface sediments can be problematic because of a rearrangement of pore structure. Columns prepared with the aid of vibratory compaction can suffer from mechanically induced radial segregation 
(i.e., a greater proportion of coarser grains at the column periphery) (187) and large columns packed with the aid of a vibration-free packer can suffer from longitudinal grain size segregation (80). A device that allows an improved degree of control over the dry packing of columns is described by Stauffer and Dracos (209). Wet-packing procedures (see, e.g., reference 103) are most often used in flow-through column experiments involving microbial transport. However, manual wet-packing procedures are not artifact free, judging from differences in apparent transport behavior of a polydispersed mixture of different-sized microspheres among replicate wet-packed columns (80). In several microbial transport studies (55, 130, 198), problems associated with spatial fractionation of grain sizes have been ameliorated by the use of smaller-diameter, shorter columns packed with sieved (prefractionated) sand. Sterilization of columns can also lead to alterations of pore structure. In particular, autoclaving porous subsurface material can lead to a reduction in the surface area of clays available for adhesion and even alterations in pore surface charge. This can result in decreased microbial penetration rates within the column relative to those in which dry heat sterilization procedures were used (97).

In addition to the packing procedure, the importance of excluding air bubbles and maintaining saturated conditions cannot be overemphasized. This is because the presence of gas bubbles can change the hydraulic properties of the column and serve as highly efficient collectors for bacteria traveling through the column. The entrapment of negatively charged bacteria and viruses within gas/water interfaces in unsaturated porous media as a result of strong forces (surface tension) and electrostatic interactions is a well-documented phenomenon (101, 171, 195, $232,233)$. Porous-medium columns may be voided of air pockets by an initial displacement of the intergranular gases with carbon dioxide, which can subsequently be voided from the system by sequentially passing solutions of calcium sulfate and degassed groundwater through the column (79). Although many saturated columns of subsurface material have been successfully run in the downflow mode (see, e.g., references 8 and 9), they are more commonly run in the upflow mode to prevent desaturation during the time course of the experiment. Columns run in a vertical position result in the flow direction and gravitational force acting along the same axis and may result in an overemphasis on sedimentation (148). This problem can be overcome by using a slight column inclination (e.g., 10') (Fig. 5A) from the horizontal (80). The Mariot siphon provides an inexpensive constant head but is limited in terms of control. Fortunately, some microprocessor-controlled piston pumps can deliver accurately and steadily at volumetric flow rates low enough (e.g., several milliliters per hour) to produce environmentally relevant flow velocities within packed columns.

Temperature can be an important factor in bacterial motility $(125,146)$, in attachment of microorganisms to surfaces, and in the inactivation rates of viruses $(7,242)$. Therefore, it is important that column and fluid temperatures are reasonably close to that of the aquifer in which the subsurface material was collected. Aquifers are thermally buffered and consequently are characterized by near constant temperatures. The most effective method of conducting a column experiment at constant temperature is to place the whole experimental assembly (column, reservoir, pump, collector, and tubing) in an environmental control room or large refrigerated incubator that is set to the temperature of the aquifer.

Flow-through columns also are useful in investigations of microbial transport behavior in the vadose zone and in surface soils. However, maintaining constant degrees of saturation in subsurface sediments during unsaturated- flow conditions in a flow-through column can be problematic. Flow in a series of unsaturated columns can be controlled by application of a partial vacuum evenly to the effluent end of the columns (Fig. 5B).

\section{Static Columns}

Static minicolumns are particularly well suited for studies of microbial attachment, taxis and chemotaxis, and survival behavior in the presence of saturated subsurface media $(119,182,184,198$, 201). Their small size facilitates the use of replicate systems and reduces the packing-related problems inherent in the use of larger columns. The absence of flow precludes hydrodynamic boundary layers which suspended microorganisms would otherwise have to cross to reach the surface. This simplifies the interpretation of microbial attachment kinetics, so that the effects of varying chemical, physical, and physiological conditions on attachment behavior in the presence of subsurface material can be more easily assessed.

Pore structure rearrangement during the sampling and repacking of subsurface material can be largely avoided in column experiments involving bacterial penetration through porous rock. This is because cores of consolidated material can be removed and handled intact for use in either flow-through or static minicolumn experiments. A number of laboratory investigations involving bacterial penetration through low-permeability $(<0.7$ $\mathrm{gm}$ '), consolidated subsurface material have been performed using Berea sandstone $(35,94,98,157,175)$, which is relatively homogeneous and available in a variety of permeability classes (148). Bacterial growth or taxis through sandstone may be assessed by using a device consisting of a stagnant nutrientsaturated sandstone core connecting two flasks, one containing sterile nutrient broth and the other containing the bacterium of interest $(94,98)$ (Fig. 5Q. The appearance of bacteria in the sterile flask establishes the time required for migration through the connecting sandstone, although differences in methods of detection (e.g., turbidity versus viable counts) can yield substantial differences in apparent travel times (35). A more thorough discussion of investigations involving growth, tactic, and chemotactic migration through sandstone is provided by McInerney (148).

\section{Tank Experiments}

Two- and three-dimensional sand tank experiments can be used, in part, to bridge the gap between column- and field scale experiments involving microbial transport through saturated porous media. Sand tanks are typically constructed on the scale of I to 10 in in length and are commonly used to study the potential of physicochemical and biological remediation of xenobiotic compounds that contaminate granular media in the subsurface (see, e.g., references 54, 104, 113, 154, and 155). However, they can also be helpful for simulating the effects of physical (e.g., grain size distribution) or geochemical (e.g., mineralogical) heterogeneity on subsurface bacterial transport behavior. This may be accomplished by the creation of structured heterogeneity within the tank. Two-dimensional tanks can be instrumented with sampling ports in a manner that has a minimal effect on flow through the tank. This can be ac 

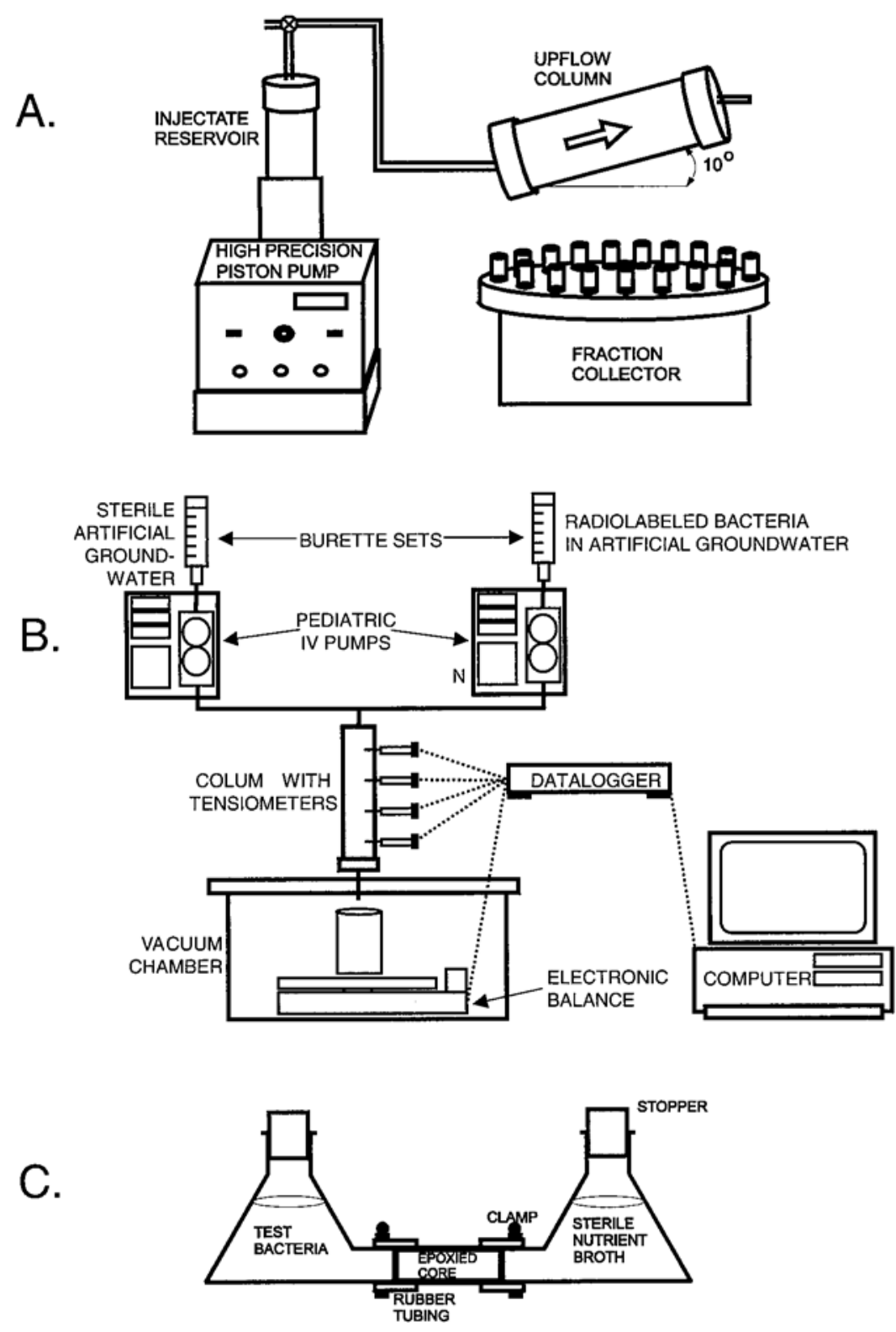

FIGURE 5 Experimental apparatuses for conducting laboratory-scale studies of microbial transport behavior in saturated subsurface media. (A) Upflow column at a slight incline to the horizontal, employing a pressure-sensitive, high-precision piston pump to supply a constant head. (B) Experimental apparatus for assessing bacterial transport in porous media as a function of water content (100). Redrawn from reference with permission of the publisher. (C) Experimental setup for examining microbial transport behavior through consolidated materials under static conditions. Modified from reference 98 with permission of the American Society for Microbiology.

complished by embedding the sampling ports along a twodimensional grid within one or both longitudinal walls. The walls are often constructed from a clear plastic material, which facilitates the creation of layered heterogeneity (93).

\section{Measurements of Bacterial Adhesion and Cell}

\section{Characteristics}

An important determinant of the subsurface transport behavior of bacteria is their interaction with the solid aquifer material, which in turn depends on the physicochemical properties of the bacteria. Accordingly, various physicochemical characterizations of bacteria and studies of their adhesion to solids and to the air/water interface have been conducted to better understand bacterial transport behavior in porous media. Experimental systems used in adhesion studies need to be designed in a manner that permits careful control of the hydrodynamic conditions so that subsequent mass transfer calculations are accurate. Systems to study bacterial adhesion to solids include batch incubations of microscope slides (184), rotating disks (142), microscope flow cells (206), and impinging jet systems (40). Micro 
scope micromodels (232), bubble tubes $(22,195)$, and quiescent water surfaces (195) were used to quantify bacterial accumulation at the air/water interface. The collision efficiency (a) can be estimated as the ratio of the observed extent of bacterial adhesion to the calculated mass transfer to the surface. However, instead of being calculated, the mass transfer can be determined directly in control adhesion experiments performed under the most favorable conditions for adhesion (where a- is assumed to approach unity). For instance, to verify mass transfer calculations in a rotating-disk system, Martin and Bouwer (142) included an adhesion experiment with their test bacteria and an oppositely charged surface and Rijnaarts et al. (185) used ionic strengths of $0.1 \mathrm{M}$ to achieve maximum adhesion by diminishing electrostatic repulsion. However, considerable caution is needed in this approach. For example, Jucker et al. (I It) have shown that repulsion originating from the lipopolysaccharide (LPS) layer could cause a for a positively charged bacterium attaching to negatively charged glass to be considerably below unity even though calculated interaction forces were strongly attractive. For a description and critical evaluation of methods to study bacterial adhesion, the reader is referred to reference 26. These authors strongly favor the use of parallel-plate microscope flow cells because of the good control of the system hydrodynamics and the bacterial transfer rate, the possibility to observe adhesion and detachment of individual cells directly and without artifact-prone manipulations, and the ability to recognize nonrandom attachment patterns indicative of processes such as substratum blocking, ripening, or coadhesion of microbial pairs.

Collision efficiencies obtained in adhesion experiments can theoretically be used to predict bacterial removal in any porous medium for which reliable mass transfer calculations can be made. However, we are unaware of studies that have succeeded in a priori prediction (simulation) of bacterial transport in aquifer materials based on independently determined collision efficiencies. This is possibly due to the lack Of sufficiently reliable mass transfer models and to the difficulty in mimicking the chemistry and surface topography of aquifer materials with model materials that can be used in adhesion experiments. Frequently, flat glass or polymeric materials were used to imitate mineral surfaces and organic matter coatings. Only a few studies included both adhesion experiments under controlled hydrodynamic conditions and transport experiments in porous media $(110,184)$ Rijnaarts et al. (184) compared the adhesion of 11 bacterial strains to glass and Teflon under diffusion controlled conditions in batch incubations and under convective diffusion in columns containing spheres of these materials. For 7 of 11 strains they found roughly four times more adhesion with both materials in the column system, which could be attributed to the more efficient mass transfer by convective diffusion as opposed to diffusion in the batch system. However, even in these simple experiments with solids of identical chemical composition and topography, three of the bacteria exhibited increased attachment in columns that coincided with deviating cell properties such as an exceptionally high aspect ratio of one of the strains, a high tendency of a second strain to detach before microscopic enumeration, and aggregation of a third strain. Decreased attachment was observed for a strain that possessed a polymer capsule. Hence, it appears that at present, independently determined collision efficiencies do not always allow one to a priori predict bacterial transport even in systems of well-characterized flow. The transferability of collision efficiencies obtained with air/water interfaces to bacterial transport in unsaturated porous materials is even more questionable because of additional uncertainties about the dimension of the air/water and the water/solid interfaces and the distribution of mobile and immobile water in vadose systems (196). These limitations neither impair the general value of adhesion experiments to predict relative differences in the transport behavior of various bacteria in a given system nor contradict with general correlations between physicochemical properties of bacteria and their transport behaviors.

Two distinct physicochemcal approaches have been applied to bacterial adhesion in the 1980s. A thermodynamic approach assumes direct contact between a surface and an adhering bacterium and describes bacterial adhesion in terms of a comparison of interfacial free energies between the interacting surfaces (3). The DLVO theory of colloidal stability calculates attractive Lifshitz-van der Waals and attractive or repulsive electrostatic interactions as a function of the separation distance (192). However, obvious deficiencies of both approaches, the neglect of obviously existing electrostatic contributions by the thermodynamic approach and the inability of the DLVO theory to explain influences of the hydrophobicity of bacteria and solids, have fostered the general acceptance of an extended DLVO theory that includes short-range Lewis acid-base (hydrophobic) interactions (230). Bacterial characteristics entering into these calculations include the cell radius (electrostatic, Lifshitz-van der Waals interactions), the Hamaker constant of bacteria (Lifshitz-van der Waals interactions), the zeta potential (electrostatic interactions), and the surface free energy, which can be split into apolar and electron-donating/electron-accepting components (hydrophobic and hydrophilic interactions).

Cell radii are measured either by dynamic light scattering (174) or microscopically, whereby, e.g., a geometric mean radius $\mathrm{R}$, = $0.5(w w l)^{1 / 3}$, where $w$ and $l$ are the width and the length, respectively, of the bacterium, has been used for rod-shaped bacteria (195). Bacterial zeta potentials are usually obtained by laser-Doppler velocimetry. Approximations of Hamaker constants of bacterial surfaces can be obtained from the Lifshitz-van der Waals interaction energy as calculated from contact angle measurements (26). However, reported ranges of Hamaker constants of standard biological materials (163) which neglect individual bacterial differences have often been used instead (184). Surface free energies are obtained by contact angle measurements (229) performed on layers of bacteria (obtained, for example, by filtration). Individual components of the surface free energy can be analyzed by measuring contact angles with at least three liquids of different polarities (228).

It should be noted, however, that some bacteria are far from being ideal colloidal particles with perfectly smooth surfaces as required by the extended DLVO theory and thus, not surprisingly, considerable discrepancies between predictions and the actual adhesion behavior have been observed. Recently, these surface irregularities have been studied by atomic force microscopy (3 1). In a detailed study of the influence of the chemistry and topography of LPS layers on bacterial adhesion $(108,110,111)$, it was suggested that irregular, compressible LPS coats can give rise to efficient and strongly irreversible adhesion to mineral surfaces that is mediated by hydrogen bonds between polysaccharides and mineral oxides and/or chemisorbed water, whereas rigid, smooth LPS layers may prevent bacterial adhesion even when the extended DLVO forces are strongly 
attractive. Inclusion of repulsive and attractive polymer interactions into an even further extended DLVO theory could account for some hitherto unexplained adhesion phenomena. However, the fact that the new theory comprises now five distinct forces with different decay functions led the authors to conclude that it is uncertain whether bacteria can be characterized rigorously enough for a reliable a priori prediction of adhesion (I Il).

\section{CONCLUSIONS}

Although microorganisms were first introduced into groundwater as tracers to gain information about the hydrology of complex groundwater environments, interest has clearly shifted to the transport behavior of the microorganisms themselves. Much of the emphasis over the last two decades has focused on column experiments because of the interpretational and technical difficulties of conducting subsurface microbial transport investigations in the field. As a consequence, the development of methodology for conducting controlled field transport investigations has lagged behind that of laboratory experiments. Flow-through- and static-column investigations offer the ability to achieve a degree of control not possible in the field. As described herein, methodology for studying specific controls of microbial transport in laboratory porous media is improving as techniques for accurately controlling flow at low (environmentally relevant) rates, isolating specific controlling factors, and quantifying the microorganisms of interest become more sophisticated. However, there is also a growing realization that processes controlling subsurface microbial transport behavior are interrelated and can be operative on spatial and temporal scales not conducive to laboratory Study. This is leading to more field-scale experiments and to research programs that involve a combination of field and laboratory Studies. Most controlled field investigations Of Subsurface microbial transport are conducted on limited spatial scales relative to the scales of interest to those concerned with pathogen transport to water supply wells, with microbially enhanced oil recovery from petroleum reservoirs, and with the feasibility of using introduced bacteria for aquifer restoration. However, continued advances in our understanding of microbial transport behavior as a result of ongoing laboratory and small-scale field investigations will facilitate future large-scale field experiments. This, in turn, will allow testing of more accurate models capable of describing subsurface microbial transport over considerable distances.

\section{REFERENCES}

1. Abba, F., Orlandi, and A. Rondelli. 1898. Über die Filtrationskraft des Bodens und die Fortschwemmung von Bakterien durch das Grundwasser. Z. Hyg. Infekt. Krankh. $31: 66-84$.

2. Abbaszadegan, M., M. S. Huber, C. P. Gerba, and I. L. Pepper. 1993. Detection of enteroviruses in groundwater with the polymerase chain reaction. Appl. Environ. Microbiol. 59:1318-1324.

3. Absolom, D. R., F. V. Lamberti, Z. Policova, W. Zingg, C. J. van Oss, and A. W. Neumann. 1983. Surface thermodynamics of bacterial adhesion. Appl. Environ. Microbiol. 46:90-97.

4. Albinger, O., B. K. Biesemeyer, R. G. Arnold, and B. E. Logan. 1994. Effect of bacterial heterogeneity on adhesion to uniform collectors by monoclonal populations. FEMS Microbiol. Lett. 124:321.
5. Albrechtsen, H. J., and A. Winding. 1992. Microbial biomass and activity in subsurface sediments from Vejen, Denmark. Microb. Ecol. 23:303-317.

6. Ammons, D., J. Rampersad, and G. E. Fox. 1998. A genomically modified marker strain of Escherichia coli. Curr. Microbiol. 37:341-346.

7. Badawy, A. S., J. B. Rose, and C. P. Gerba. 1990. Comparative survival of enteric viruses and coliphage on sewage irrigated grass. J. Environ. Sci. Health Part A 25:937952.

8. Bales, R. C., C. P. Gerba, G. H. Grondin, and S. L. Jensen. 1989. Bacteriophage transport in sandy soil and fractured tuff. Appl. Environ. Microbiol. 55:2061-2067.

9. Bales, R. C., S. R. Hinkle, T. W. Kroeger, K. Stocking, and C. P. Gerba. 1991. Bacteriophage adsorption during transport through porous media-chemical perturbations and reversibility. Environ. Sci. Technol. 25:2088-2095.

10. Bales, R. C., S. M. Li, K. M. Maguire, M. T. Yahya, and C. P. Gerba. 1993. Ms-2 and poliovirus transport in porous media-hydrophobic effects and chemical perturbations. Water Resour. Res. 29:957-963.

11. Bales, R. C., S. M. Li, K. M. Maguire, M. T. Yahya, C. P. Gerba, and R. W. Harvey. 1995. Virus and bacteria transport in a sandy aquifer, Cape Cod, Ma. Ground Water 33:653-661.

12. Bales, R. C., S. M. Li, T. C. J. Yeh, M. E. Lenczewski, and C. P. Gerba. 1997. Bacteriophage and microsphere transport in saturated porous media: forced-gradient experiment at Borden, Ontario. Water Resour. Res. 33:639648.

13. Barton, J. W., and R. M. Ford. 1995. Determination of effective transport coefficients for bacterial migration in sand columns. Appl. Environ. Microbiol. 61:3329-3335.

14. Baveye, P., P. Vandevivere, B. L. Hoyle, P. C. DeLeo, and D. S. de Lozada. 1998. Environmental impact and mechanisms of the biological clogging of saturated soils and aquifer materials. Crit. Rev. Environ. Sci. Technol. 28: 123-191.

15. Baygents, J. C., J. R. Glynn, O. Albinger, B. K. Biesemeyer, K. L. Ogden, and R. G. Arnold. 1998. Variation of surface charge density in monoclonal bacterial populations: implications for transport through porous media. Environ. Sci. Technol. 32:1596-1603.

16. Becker, M. W., P. W. Reimus, and P. Vilks. 1999. Transport and attenuation of carboxylate-modified latex microspheres in fractured rock laboratory and field tracer tests. Ground Water 37:387-395.

17. Beeder, J., R. K. Nilsen, T. Thorstenson, and T. Torsvik. 1996. Penetration of sulfate reducers through a porous North Sea oil reservoir. Appl. Environ. Microbiol. 62: 3551-3553.

18. Bengtsson, G., and R. Lindqvist. 1995. Transport of soil bacteria controlled by density-dependent sorption kinetics. Water Resour. Res. 31:1247-1256.

19. Beres, M., A. Green, P. Huggenberger, and $H$. Horstmeyer. 1995. Mapping the architecture of glaciofluvial sediments with 3-dimensional georadar. Geology 23:1087-1090.

20. Beres, M., P. Huggenberger, A. G. Green, and H. Horstmeyer. 1999. Using two- and three-dimensional georadar methods to characterize glaciofluvial architecture. Sediment. Geol. 129:1-24.

21. Bitton, G., and R. W. Harvey. 1992. Transport of pathogens through soils and aquifers, p. 103-124. In R. Mitchell (ed.), Environmental Microbiology. Wiley-Liss, New York, N.Y.

22. Blanchard, D. C., and D. L. Syzdek. 1974. Bubble tube: apparatus for determining rate of collection of bacteria by a bubble rising in water. Limnol. Oceanogr. 23:133-138. 
23. Boadu, F. K. 2000. Hydraulic conductivity of soils from grain-size distribution: new models. J. Geotechnol. Geoenviron. Eng. 126:739-746.

24. Bolster, C. H., G. M. Hornberger, A. L. Mills, and J. L. Wilson. 1998. A method for calculating bacterial deposition coefficient using the fraction of bacteria recovered from laboratory columns. Environ. Sci. Technol. 32:1329-1332.

25. Bolster, C. H., A. L. Mills, G. M. Hornberger, and J. S. Herman. 1999. Spatial distribution of deposited bacteria following miscible displacement experiments in intact cores. Water Resour. Res. 35:1797-1807.

26. Bos, R., H. C. van der Mei, and H. J. Busscher. 1999. Physico-chemistry of initial microbial adhesive interactions-its mechanisms and methods for study. FEMS Microbiol. Rev. 23:179-230.

27. Bouwer, H. 1978. Groundwater Hydrology. McGraw-Hill Book Co., New York, N.Y.

28. Brush, C. F., W. C. Ghiorse, L. J. Anguish, J. Y. Parlange, and H. G. Grimes. 1999. Transport of Cryptosporidium parvum oocysts through saturated columns. J. Environ. Qual. 28:809-815.

29. Burlage, R. S., Z. K. Yang, and T. Mehlhorn. 1996. A transposon for green fluorescent protein transcriptional fusions: application for bacterial transport experiments. Gene 173:53-58.

30. Camesano, T. A., and B. E. Logan. 1998. Influence of fluid velocity and cell concentration on the transport of motile and nonmotile bacteria in porous media. Environ. Sci. Technol. 32:1699-1708.

31. Camesano, T. A., M. J. Natan, and B. E. Logan. 2000. Observation of changes in bacterial cell morphology using tapping mode atomic force microscopy. Langmuir 16: 4563-4572.

32. Camper, A. K., J. T. Hayes, P. J. Sturman, W. L. Jones, and A. B. Cunningham. 1993. Effects of motility and adsorption rate coefficient on transport of bacteria through saturated porous media. Appl. Environ. Microbiol. 59: 3455-3462.

33. Chalfie, M., Y. Tu, G. Euskirchen, W. W. Ward, and D. C. Prasher. 1994. Green fluorescent protein as a marker for gene expression. Science 263:802-805.

34. Champ, D. R., and J. Schroeter. 1988. Bacterial transport in fractured rock-a field-scale tracer test at the Chalk River Nuclear Laboratories. Water Sci. Technol. 20:81-87.

35. Chang, P. L., and T. F. Yen. 1985. Interaction of Pseudomonas putida ATCC 12633 and bacteriophage gh-1 in Berea sandstone rock. Appl. Environ. Microbiol. 59:34553462.

36. Chen, J., and B. Koopman. 1997. Effect of fluorochromes on bacterial surface properties and interaction with granular media. Appl. Environ. Microbiol. 63:3941-3945.

37. Colwell, F. S., G. J. Stormberg, T. J. Phelps, S. A. Birnbaum, J. McKinley, S. A. Rawson, C. Veverka, S. Goodwin, P. E. Long, B. F. Russell, T. Garland, D. Thompson, P. Skinner, and S. Grover. 1992. Innovative techniques for collection of saturated and unsaturated subsurface basalts and sediments for microbiological characterization. J. Microbiol. Methods 15:279-292.

38. Corapcioglu, M. Y., and S. H. Kim. 1995. Modeling facilitated contaminant transport by mobile bacteria. Water Resour. Res. 31:2639-2647.

39. Cusack, F., S. Singh, C. McCarthy, J. Grieco, M. Derocco, D. Nguyen, H. Lappinscott, and J. W. Costerton. 1992. Enhanced oil-recovery-3-dimensional sandpack simulation of ultramicrobacteria resuscitation in reservoir formation. J. Gen. Microbiol. 138:647-655.

40. Dabros, T., and T. G. M. van de Ven. 1987. Deposition of latex particles on glass surfaces in an impinging jet. Phys. Chem. Hydrodynam. 8:161-172.
41. Daniell, T. J., M. L. Davy, and R. J. Smith. 2000. Development of a genetically modified bacteriophage for use in tracing sources of pollution. J. Appl. Microbiol. 88:860869.

42. DeFlaun, M. F., C. J. Murray, W. Holben, T. Scheibe, A. Mills, T. Ginn, T. Griffin, E. Majer, and J. L. Wilson. 1997. Preliminary observations on bacterial transport in a coastal plain aquifer. FEMS Microbiol. Rev. 20:473-487.

43. DeFlaun, M. F., S. R. Oppenheimer, S. Streger, C. W. Condee, and M. Fletcher. 1999. Alterations in adhesion, transport, and membrane characteristics in an adhesiondeficient pseudomonad. Appl. Environ. Microbiol. 65:759765.

44. DeLeo, P. C., and P. Baveye. 1996. Enumeration and biomass estimation of bacteria in aquifer microcosm studies by flow cytometry. Appl. Environ. Microbiol. 62:45804586.

45. Deshpande, P. A., and D. R. Shonnard. 2000. An improved spectrophotometric method to study the transport, attachment, and breakthrough of bacteria through porous media. Appl. Environ. Microbiol. 66:763-768.

46. Deshpande, P. A., and D. R. Shonnard. 1999. Modeling the effects of systematic variation in ionic strength on the attachment kinetics of Pseudomonas fluorescens UPER-1 in saturated sand columns. Water Resour. Res. 35:16191627.

47. Dong, H. L., T. C. Onstott, M. F. DeFlaun, M. E. Fuller, K. M. Gillespie, and J. K. Fredrickson. 1999. Development of radiographic and microscopic techniques for the characterization of bacterial transport in intact sediment cores from Oyster, Virginia. J. Microbiol. Methods 37:139154.

48. Dowd, S. E., S. D. Pillai, S. Y. Wang, and M. Y. Corapcioglu. 1998. Delineating the specific influence of virus isoelectric point and size on virus adsorption and transport through sandy soils. Appl. Environ. Microbiol. 64:405-410.

49. Dubois, S. M., B. E. Moore, and S. P. Sagik. 1976. Poliovirus survival and movement in a sandy forest soil. Appl. Environ. Microbiol. 31:536-543.

50. Duffy, K. J., P. T. Cummings, and R. M. Ford. 1995. Random-walk calculations for bacterial migration in porous-media. Biophys. J. 68:800-806.

51. Eisenmann, H., H. Harms, R. Meckenstock, E. I. Meyer, and A. J. B. Zehnder. 1998. Grazing of a Tetrahymena sp. on adhered bacteria in percolated columns monitored by in situ hybridization with fluorescent oligonucleotide probes. Appl. Environ. Microbiol. 64:12641269.

52. Elowitz, M. B., M. G. Surette, P. E. Wolf, J. Stock, and S. Leibler. 1997. Photoactivation turns green fluorescent protein red. Curr. Biol. 7:809-812.

53. Fang, Y., and B. E. Logan. 1999. Bacterial transport in gas-sparged porous medium. J. Environ. Eng.-ASCE 125:668-673.

54. Fischer, U., R. Schulin, M. Keller, and F. Stauffer. 1996. Experimental and numerical investigation of soil vapor extraction. Water Resour. Res. 32:3413-3427.

55. Fontes, D. E., A. L. Mills, G. M. Hornberger, and J. S. Herman. 1991. Physical and chemical factors influencing transport of microorganisms through porous media. Appl. Environ. Microbiol. 57:2473-2481.

56. Fortineau, N., P. Trieu-Cuot, O. Gaillot, E. Pellegrini, P. Berche, and J. L. Gaillard. 2000. Optimization of green fluorescent protein expression vectors for in vitro and in vivo detection of Listeria monocytogenes. Res. Microbiol. $151: 353-360$.

57. Freeze, R. A., and J. A. Cherry. 1979. Groundwater. Prentice-Hall, Englewood Cliffs, N.J. 
58. Fuller, M. E., S. H. Steger, R. K. Rothmel, B. J. Mailloux, J. A. Hall, T. C. Onstott, J. K. Fredrickson, D. L. Balkwill, and M. F. DeFlaun. 2000. Development of a vital fluoresecent staining method for monitoring bacterial transport in subsurface environments. Appl. Environ. Microbiol. 66:4486-4496.

59. Gallop, P. M., M. A. Paz, E. Henson, and S. A. Latt. 1984. Dynamic approaches to the delivery of reporter reagents into living cells. BioTechniques 1:32-36.

60. Gannon, J., Y. H. Tan, P. Baveye, and M. Alexander. 1991. Effect of sodium chloride on transport of bacteria in a saturated aquifer material. Appl. Environ. Microbiol. $57: 2497-2501$.

61. Gannon, J. T., V. B. Manilal, and M. Alexander. 1991. Relationship between cell surface properties and transport of bacteria through soil. Appl. Environ. Microbiol. 57:190193.

62. Garabedian, S. P., D. R. Leblanc, L. W. Gelhar, and M. A. Celia. 1991. Large-scale natural gradient tracer test in sand and gravel, Cape Cod, Massachusetts. 2. Analysis of spatial moments for a nonreactive tracer. Water Resour. Res. 27:911-924.

63. Glynn, J. R., B. M. Belongia, R. G. Arnold, K. L. Ogden, and J. C. Baygents. 1998. Capillary electrophoresis measurements of electrophoretic mobility for colloidal particles of biological interest. Appl. Environ. Microbiol. 64:2572-2577.

64. Goltz, M. N., and P. V. Roberts. 1987. Using the method of moments to analyze 3-dimensional diffusion-limited solute transport from temporal and spatial perspectives. Water Resour. Res. 23:1575-1585.

65. Graham, D. W., D. G. Korich, R. P. Leblanc, N. A. Sinclair, and R. G. Arnold. 1992. Applications of a colorimetric plate assay for soluble methane monooxygenase activity. Appl. Environ. Microbiol. 58:2231-2236.

66. Grasso, D., B. F. Smets, K. A. Strevett, B. D. Machinist, C. J. VanOss, R. F. Giese, and W. Wu. 1996. Impact of physiological state on surface thermodynamics and adhesion of Pseudomonas aeruginosa. Environ. Sci. Technol. 30: 3604-3608.

67. Groffman, P. M., A. J. Gold, and G. Howard. 1995. Hydrologic tracer effects on soil microbial activities. Soil Sci. Soc. Am. J. 59:478-481.

68. Gross, M. J., O. Albinger, D. G. Jewett, B. E. Logan, R. C. Bales, and R. G. Arnold. 1995. Measurement of bacterial collision efficiencies in porous media. Water Res. 29:1151-1158.

69. Gross, M. J., and B. E. Logan. 1995. Influence of different chemical treatments on transport of Alcaligenes paradoxus in porous media. Appl. Environ. Microbiol. 61:1750 1756.

70. Guimares, V. F., I. V. Cruz, A. N. Hagler, L. C. Mendonca-Hagler, and J. D. van Elsas. 1997. Transport of a genetically modified Pseudomonas fuorescens and its parent strain through undisturbed tropical soil cores. Appl. Soil Ecol. 7:41-50.

71. Harms, H., and T. N. P. Bosma. 1997. Mass transfer limitation of microbial growth and pollutant degradation. J. Ind. Microbiol. Biotechnol. 18:97-105.

72. Harms, H., and A. J. B. Zehnder. 1994. Influence of substrate diffusion on degradation of dibenzofuran and 3 . chlorodibenzofuran by attached and suspended bacteria. Appl. Environ. Microbiol. 60:2736-2745.

73. Hart, A., and C. Edwards. 1987. Buoyant densityfluctuations during the cell-cycle of Bacillus subtilis. Arch. Microbiol. 147:68-72.

74. Harter, T., S. Wagner, and E. R. Atwill. 2000. Colloid transport and filtration of Cryptosporidium parvum in sandy soils and aquifer sediments. Environ. Sci. Technol. 34:6270 .

75. Harvey, R. W. 1991. Parameters involved in modeling movement of bacteria in groundwater, p. 89-114. In C. J. Hurst (ed.), Modeling the Environmental Fate of Microorganisms. American Society for Microbiology, Washington, D.C.

76. Harvey, R. W., and S. P. Garabedian. 1991. Use of colloid filtration theory in modeling movement of bacteria through a contaminated sandy aquifer. Environ. Sci. Technol. 25:178-185.

77. Harvey, R. W., and L. H. George. 1987. Growth determinations for unattached bacteria in a contaminated aquifer. Appl. Environ. Microbiol. 53:2992-2996.

78. Harvey, R. W., L. H. George, R. L. Smith, and D. R. Leblanc. 1989. Transport of microspheres and indigenous bacteria through a sandy aquifer: results of naturalgradient and forced-gradient tracer experiments. Environ. Sci. Technol. 23:51-56.

79. Harvey, R. W., N. E. Kinner, A. Bunn, D. Macdonald, and D. Metge. 1995. Transport behavior of groundwater protozoa and protozoan-sized microspheres in sandy aquifer sediments. Appl. Environ. Microbiol. 61:209-217.

80. Harvey, R. W., N. E. Kinner, D. Macdonald, D. W. Metge, and A. Bunn. 1993. Role of physical heterogeneity in the interpretation of small-scale laboratory and field observations of bacteria, microbial-sized microspheres, and bromide transport through aquifer sediments. Water Resour. Res. 29:2713-2721.

81. Harvey, R. W., D. W. Metge, N. Kinner, and N. Mayberry. 1997. Physiological considerations in applying laboratory-determined buoyant densities to predictions of bacterial and protozoan transport in groundwater: results of in situ and laboratory tests. Environ. Sci. Technol. 31: 289-295.

82. Heise, S., and G. Gust. 1999. Influence of the physiological status of bacteria on their transport into permeable sediments. Mar. Ecol. Prog. Ser. 190:141-153.

83. Heitzer, A., B. Applegate, S. Kehrmeyer, H. Pinkart, O. F. Webb, T. J. Phelps, D. C. White, and G. S. Sayler. 1998. Physiological considerations of environmental applications of lux reporter fusions. J. Microbiol. Methods 33: 45-57.

84. Hekman, W. E., C. E. Heijnen, S. Burgers, J. A. Vanveen, and J. D. Vanelsas. 1995. Transport of bacterial inoculants through intact cores of 2 different soils as affected by water percolation and the presence of wheat plants. FEMS Microbiol. Ecol. 16:143-157.

85. Hendry, M. J., J. R. Lawrence, and P. Maloszewski. 1997. The role of sorption in the transport of Klebsiella oxytoca through saturated silica sand. Ground Water 35: 574-584.

86. Hess, K. M., S. H. Wolf, and M. A. Celia. 1992. Largescale natural gradient tracer test in sand and gravel, Cape Cod, Massachusetts. 3. Hydraulic conductivity variability and calculated macrodispersivities. Water Resour. Res. 28: 2011-2027.

87. Hobbie, J. E., R. J. Daley, and S. Jasper. 1977. Use of Nuclepore filters for counting bacteria by fluorescence microscopy. Appl. Environ. Microbiol. 33:1225-1228.

88. Holben, W. E., and P. H. Ostrom. 2000. Monitoring bacterial transport by stable isotope enrichment of cells. Appl. Environ. Microbiol. 66:4935-4939.

89. Hornberger, G. M., A. L. Mills, and J. S. Herman. 1992. Bacterial transport in porous media-evaluation of a model using laboratory observations. Water Resour. Res. 28:915-923.

90. Huggenberger, P., E. Meier, and A. Pugin. 1994. Ground-probing radar as a tool for heterogeneity estima- 
tion in gravel deposits - advances in data-processing and facies analysis. J. Appl. Geophys. 31:171-184.

91. Hurst, C. J. (ed.). 1991. Modeling the Environmental Fate of Microorganisms. American Society for Microbiology, Washington, D.C.

92. Huysman, F., and W. Verstraete. 1993. Water-facilitated transport of bacteria in unsaturated soil columnsinfluence of cell-surface hydrophobicity and soil properties. Soil Biol. Biochem. 25:83-90.

93. Illangasekare, T. H., E. J. Armbruster, and D. N. Yates. 1995. Non-aqueous-phase fluids in heterogeneous aquifers: experimental study. J. Environ. Eng.-ASCE 121:571-579.

94. Jang, L. K., P. W. Chang, J. E. Findley, and T. F. Yen. 1983. Selection of bacteria with favorable transportproperties through porous rock for the application of microbial-enhanced oil recovery. Appl. Environ. Microbiol. 46:1066-1072.

95. Jaspers, M. C. M., S. Totevova, K. Demnerova, H. Harms, and J. R. van der Meer. 1999. The use of wholecell living biosensors to determine the bioavailability of pollutants to microorganisms, p. 153-158. In P. Baveye, J. C. Block, and V. V. Goncharuk (ed.), Bioavailability of Organic Xenobiotics in the Environment. Kluwer Academic Publishers, London, United Kingdom.

96. Jenkins, M. B., and L. W. Lion. 1993. Mobile bacteria and transport of polynuclear aromatic hydrocarbons in porous media. Appl. Environ. Microbiol. 59:3306-3313.

97. Jenneman, G. E., M. J. McInerney, M. E. Crocker, and R. M. Knapp. 1986. Effect of sterilization by dry heat or autoclaving on bacterial penetration through Berea sandstone. Appl. Environ. Microbiol. 51:39-43.

98. Jenneman, G. E., M. J. McInerney, and R. M. Knapp. 1985. Microbial penetration through nutrient-saturated Berea sandstone. Appl. Environ. Microbiol. 50:383-391.

99. Jewett, D. G., T. A. Hilbert, B. E. Logan, R. G. Arnold, and R. C. Bales. 1995. Bacterial transport in lahoratory columns and filters: influence of ionic strength and $\mathrm{pH}$ on collision efficiency. Water Res. 29:16731680 .

100. Jewett, D. G., B. E. Logan, R. G. Arnold, and R. C. Bales. 1999. Transport of Pseudomonas fluorescens strain P17 through quartz sand columns as a function of water content J. Contam. Hydrol. 36:73-89.

101. Jin, Y., Y. J. Chu, and Y. S. Li. 2000. Virus removal and transport in saturated and unsaturated sand columns. J. Contam. Hydrol. 43:111-128.

102. Jin, Y., M. V. Yates, S. S. Thompson, and W. A. Jury. 1997. Sorption of viruses during flow through saturated sand columns. Environ. Sci. Technol. 31:548-555.

103. Johnson, M. J. 1990. M.S. thesis. University of New Hampshire, Durham.

104. Johnson, T. E., and D. K. Kreamer. 1994. Physical and mathematical modeling of diesel fuel liquid and vapor movement in porous media. Ground Water 32:551-560.

105. Johnson, W. P., K. A. Blue, B. E. Logan, and R. G. Arnold. 1995. Modeling bacterial detachment during transport through porous media as a residence-timedependent process. Water Resour. Res. 31:2649-2658.

106. Johnson, W. P., and B. E. Logan. 1996. Enhanced transport of bacteria in porous media by sediment-phase and aqueous-phase natural organic matter. Water Res. 30: 923-931.

107. Johnson, W. P., P. Zhang, M. E. Fuller, T. D. Scheibe, B. J. Mailloux, T. C. Onstott, M. F. DeFlaun, S. S. Hubbard, J. Radtke, W. P. Kovacik, and W. Holben. 2001. Ferrographic tracking of bacterial transport in the field at the Narrow Channel Focus Area, Oyster, VA. Environ. Sci. Technol. 35:182-191.
108. Jucker, B. A., H. Harms, S. J. Hug, and A. J. B. Zehnder. 1997. Adsorption of bacterial surface polysaccharides on mineral oxides is mediated by hydrogen bonds. Colloid Surf. B 9:331-343.

109. Jucker, B. A., H. Harms, and A. J. B. Zehnder. 1996. Adhesion of the positively charged bacterium Stenotrophomonas (Xanthomonas) maltophilia 70401 to glass and Teflon. J. Bacteriol. 178:5472-5479.

110. Jucker, B. A., H. Harms, and A. J. B. Zehnder. 1998. Polymer interactions between five gram-negative bacteria and glass investigated using LPS micelles and vesicles as model systems. Colloid Surf. B 11:33-45.

111. Jucker, B. A., A. J. B. Zehnder, and H. Harms. 1998. Quantification of polymer interactions in bacterial adhesion. Environ. Sci. Technol. 32:2909-2915.

112. Karatani, H., T. Wilson, and J. W. Hastings. 1992. A blue fluorescent protein from a yellow-emitting luminous bacterium. Photochem. Photobiol. 55:293-299.

113. Katz, Y., and H. Gvirtzman. 2000. Capture and cleanup of a migrating VOC plume by the in-well vapor stripping: a sand tank experiment. J. Contam. Hydrol. 43: $25-44$.

114. Kemp, J. S., E. Paterson, S. M. Gammack, M. S. Cresser, and K. Killham. 1992. Leaching of genetically modified Pseudomonas fluorescens through organic soilsinfluence of temperature, soil $\mathrm{pH}$, and roots. Biol. Fertil. Soils 13:218-224.

114a.Kennedy, K. G. 2001. Ph.D. thesis. University of Neuchâtel, Neuchâtel, Switzerland.

114b.Kennedy, K. G. 2000. Bacteriophages as particle migration indicators in subsurface environments, p. 151-158. In A. Dassargues (ed.), Tracers and Modelling in Hydrogeology. IAHS Red Book Publication No. 262. International Association of Hydrological Sciences Press, Wallingford, United Kingdom.

115. Kim, S. H., and M. Y. Corapcioglu. 1996. A kinetic approach to modeling mobile bacteria-facilitated groundwater contaminant transport. Water Resour. Res. 32:321331.

116. Kinner, N. E., R. W. Harvey, and M. Kazmierkiewicz Tabaka. 1997. Effect of flagellates on free-living bacterial abundance in an organically contaminated aquifer. FEMS Microbiol. Rev. 20:249-259.

117. Kinoshita, T., R. C. Bales, K. M. Maguire, and C. P. Gerba. 1993. Effect of $\mathrm{pH}$ on bacteriophage transport through sandy soils. J. Contam. Hydrol. 14:55-70.

118. Kinoshita, T., R. C. Bales, M. T. Yahya, and C. P. Gerba. 1993. Bacteria transport in a porous medium: retention of Bacillus and Pseudomonas on silica surfaces. Water Res. 27:1295-1301.

119. Krumme, M. L., R. L. Smith, J. Egestorff, S. M. Thiem, J. M. Tiedje, K. N. Timmis, and D. F. Dwyer. 1994. Behavior of pollutant-degrading microorganisms in aquifers-predictions for genetically-engineered organisms. Environ. Sci. Technol. 28:1134-1138.

120. Kucukcolak, E., B. Koopman, G. Bitton, and S. Farrah. 1998. Validity of fluorochrome-stained bacteria as tracers of short-term microbial transport through porous media. J. Contam. Hydrol. 31:349-357.

121. Kuwabara, J. S., and R. W. Harvey. 1990. Application of a hollow-fiber, tangential-flow device for sampling suspended bacteria and particles from natural waters. J. Environ. Qual. 19:625-629.

122. Lahlou, M., H. Harms, D. Springael, and J. J. OrtegaCalvo. 2000. Influence of soil components on the transport of polycyclic aromatic hydrocarbon-degrading bacteria through saturated porous media. Environ. Sci. Technol. 34:3649-3656. 
123. Lance, J. C., and C. P. Gerba. 1984. Virus movement in soil during saturated and unsaturated flow. Appl. Environ. Microbiol. 47:335-337.

124. Leblanc, D. R., S. P. Garabedian, K. M. Hess, L. W. Gelhar, R. D. Quadri, K. G. Stollenwerk, and W. W. Wood. 1991. Large-scale natural gradient tracer test in sand and gravel, Cape Cod, Massachusetts. 1. Experimental design and observed tracer movement. Water Resour. Res. 27:895-910.

125. Lewus, P., and R. M. Ford. 1999. Temperature-sensitive motility of Sulfolobus acidocaldarius influences population distribution in extreme environments. J. Bacteriol. 181: 4020-4025.

126. Li, B. L., C. Loehle, and D. Malon. 1996. Microbial transport through heterogeneous porous media: random walk, fractal, and percolation approaches. Ecol. Modell. $85: 285-302$.

127. Li, Q., and B. E. Logan. 1999. Enhancing bacterial transport for bioaugmentation of aquifers using low ionic strength solutions and surfactants. Water Res. 33:1090_ 1100 .

128. Lindlow, S. E., A. C. Amy, W. R. Barchet, and C. D. Upper. 1978. The role of bacterial ice nuclei in frost injury to sensitive plants, p. 249-263. In P. Li (ed.), Plant Cold Hardiness and Freezing Stress. Academic Press, Inc., New York, N.Y.

129. Lindqvist, R., and G. Bengtsson. 1995. Diffusionlimited and chemical-interaction-dependent sorption of soil bacteria and microspheres. Soil Biol. Biochem. 27: 941-948.

130. Lindqvist, R., and G. Bengtsson. 1991. Dispersal dynamics of groundwater bacteria. Microb. Ecol. 21:49-72.

131. Lindqvist, R., J. S. Cho, and C. G. Enfield. 1994. A kinetic model for cell-density dependent bacterial transport in porous media. Water Resour. Res. 30:3291-3299.

132. Lindqvist, R., and C. G. Enfield. 1992. Biosorption of dichlorodiphenyltrichloroethane and hexachlorobenzene in groundwater and its implications for facilitated transport. Appl. Environ. Microbiol. 58:2211-2218.

133. Lindqvist, R., and C. G. Enfield. 1992. Cell-density and nonequilibrium sorption effects on bacterial dispersal in groundwater microcosms. Microb. Ecol. 24:25-41.

134. Logan, B. E., D. G. Jewett, R. G. Arnold, E. J. Bouwer, and C. R. Omelia. 1995. Clarification of clean-bed filtration models. J. Environ. Eng.-ASCE 121:869-873.

135. Logan, B. E., D. G. Jewett, R. G. Arnold, E. J. Bouwer, and C. R. Omelia. 1997. Clarification of clean-bed filtration models: closure. J. Environ. Eng.-ASCE 123: 730-731.

136. Loveland, J. P., J. N. Ryan, G. L. Amy, and R. W. Harvey. 1996. The reversibility of virus attachment to mineral surfaces. Colloid Surf. A 107:205-221.

137. Mace, R. E. 1999. Estimation of hydraulic conductivity in large-diameter, hand-dug wells using slug-test methods. J. Hydrol. 219:34-45.

138. Macleod, F. A., H. M. Lappinscott, and J. W. Costerton. 1988. Plugging of a model rock system by using starved bacteria. Appl. Environ. Microbiol. 54:13651372.

139. Macler, B. A., and J. C. Merkle. 2000. Current knowledge on groundwater microbial pathogens and their control. Hydrogeol. J. 8:29-40.

140. Martin, M. J., B. E. Logan, W. P. Johnson, D. G. Jewett, and R. G. Arnold. 1996. Scaling bacterial filtration rates in different sized porous media. J. Environ. Eng.ASCE 122:407-415.

141. Martin, R., and A. Thomas. 1974. An example of the use of bacteriophage as a groundwater tracer. J. Hydrol. $23: 73-78$.
142. Martin, R. E., and E. J. Bouwer. 1991. Determination of bacterial collision efficiencies in a rotating disk system. Environ. Sci. Technol. 25:2075-2082.

143. Martin, R. E., E. J. Bouwer, and L. M. Hanna. 1992. Application of clean-bed filtration theory to bacterial deposition in porous media. Environ. Sci. Technol. 26: 1053-1058.

144. Mas, J., C. Pedrosalio, and R. Guerrero. 1989. Variations in cell-size and buoyant density of Escherichia coliK12 during glycogen accumulation. FEMS Microbiol. Lett. 57:231-236.

145. Mawdsley, J. L., A. E. Brooks, and R. J. Merry. 1996. Movement of the protozoan pathogen Cryptosporidium parvum through three contrasting soil types. Biol. Fertil. Soils 21:30-36.

146. McCaulou, D. R., R. C. Bales, and R. G. Arnold. 1995. Effect of temperature-controlled motility on transport of bacteria and microspheres through saturated sediment. Water Resour. Res. 31:271-280.

147. McCaulou, D. R., R. C. Bales, and J. F. McCarthy. 1994. Use of short-pulse experiments to study bacteria transport through porous media. J. Contam. Hydrol. 15: $1-14$.

148. McInerney, M. J. 1991. Use of models to predict bacterial penetration and movement within a subsurface matrix, p. 115-135. In C. J. Hurst (ed.), Modeling the Environmental Fate of Microorganisms. American Society for Microbiology, Washington, D.C.

149. McKay, L. D., J. A. Cherry, R. C. Bales, M. T. Yahya, and C. P. Gerba. 1993. A field example of bacteriophage as tracers of fracture flow. Environ. Sci. Technol. 27: 1075-1079.

150. McKay, L. D., W. E. Sanford, and J. M. Strong. 2000. Field-scale migration of colloidal tracers in a fractured shale saprolite. Ground Water 38:139-147.

151. McKay, L. D., P. L. Stafford, and L. E. Toran. 1997. EPM modeling of a field-scale tritium tracer experiment in fractured, weathered shale. Ground Water 35:9971007.

152. Miller, W. G., and S. E. Lindow. 1997. An improved GFP cloning cassette designed for prokaryotic transcriptional fusions. Gene 191:149-153.

153. Mills, A. L., J. S. Herman, G. M. Hornberger, and T. H. Dejesus. 1994. Effect of solution ionic strength and iron coatings on mineral grains on the sorption of bacterial cells to quartz sand. Appl. Environ. Microbiol. 60:3300-3306.

154. Mohammed, N., and R. I. Allayla. 2000. Effect of groundwater velocity on pilot scale bioremediation of gasoline contaminated sandy aquifers. Water Air Soil Pollut. 120:315-329.

155. Mohammed, N., and R. I. Allayla. 1997. Modeling transport and biodegradation of BTX compounds in saturated sandy soil. J. Hazard. Mater. 54:155-174.

156. Mohanty, B. P., R. S. Kanwar, and C. J. Everts. 1994. Comparison of saturated hydraulic conductivity measurement methods for a glacial-till soil. Soil Sci. Soc. Am. J. 58:672-677

157. Montgomery, A. D., M. J. McInerney, and K. L. Sublette. 1990. Microbial control of the production of hydrogen-sulfide by sulfate-reducing bacteria. Biotechnol. Bioeng. 35:533-539.

158. Morley, L. M., G. M. Hornberger, A. L. Mills, and J. S. Herman. 1998. Effects of transverse mixing on transport of bacteria through heterogeneous porous media. Water Resour. Res. 34:1901-1908.

159. Murphy, E. M., and T. R. Ginn. 2000. Modeling microbial processes in porous media. Hydrogeol. J. 8:142158. 
160. Murray, J. P., and S. Laband. 1979. Degradation of poliovirus by adsorption on inorganic surfaces. Appl. Environ. Microbiol. 37:480-486.

161. Niehren, S., and W. Kinzelbach. 1998. Artificial colloid tracer tests: development of a compact on-line microsphere counter and application to soil column experiments. J. Contam. Hydrol. 35:249-259.

162. Niehren, S., W. Kinzelbach, S. Seeger, and J. Wolfrum. 1995. An all-solid-state flow cytometer for counting fluorescent microspheres. Anal. Chem. 67:2666-2671.

163. Nir, S. 1976. Van der Waals interactions between surfaces of biological interest. Prog. Surf. Sci. 8:1-58.

164. Pang, L. P., M. Close, and M. Noonan. 1998. Rhodamine WT and Bacillus subtilis transport through an alluvial gravel aquifer. Ground Water 36:112-122.

165. Parolin, C., A. Montecucco, G. Ciarrocchi, G. Pedralinoy, S. Valisena, M. Palumbo, and G. Palu. 1990. The effect of the minor groove binding-agent dapi (2amidino-diphenyl-indole) on DNA-directed enzymes: an attempt to explain inhibition of plasmid expression in Escherichia coli. FEMS Microbiol. Lett. 68:341-346.

166. Pedrosalio, C., J. Mas, and R. Guerrero. 1985. The influence of poly-beta-hydroxybutyrate accumulation on cell volume and buoyant density in Alcaligenes eutrophus. Arch. Microbiol. 143:178-184.

167. Petushkov, V. N., and J. Lee. 1997. Purification and characterization of flavoproteins and cytochromes from the yellow bioluminescence marine bacterium Vibrio fischeri strain Y1. Eur. J. Biochem. 245:790-796.

168. Pickens, J. F., J. A. Cherry, G. E. Grisak, W. F. Merritt, and B. A. Risto. 1978. A multilevel device for groundwater sampling and piezometric monitoring. Ground Water 16:322-327.

169. Pieper, A. P., J. N. Ryan, R. W. Harvey, G. L. Amy, T. H. Illangasekare, and D. W. Metge. 1997. Transport and recovery of bacteriophage PRD1 in a sand and gravel aquifer: effect of sewage-derived organic matter. Environ. Sci. Technol. 31:1163-1170.

170. Powelson, D. K., and C. P. Gerba. 1994. Virus removal from sewage effluents during saturated and unsaturated flow-through soil columns. Water Res. 28:2175-2181.

171. Powelson, D. K., and A. L. Mills. 1996. Bacterial enrichment at the gas-water interface of a laboratory apparatus. Appl. Environ. Microbiol. 62:2593-2597.

172. Powelson, D. K., and A. L. Mills. 1998. Water saturation and surfactant effects on bacterial transport in sand columns. Soil Sci. 163:694-704.

173. Powelson, D. K., J. R. Simpson, and C. P. Gerba. 1991. Effects of organic matter on virus transport in unsaturated flow. Appl. Environ. Microbiol. 57:2192-2196.

174. Pusey, P. N., and J. A. Tough. 1985. Particle interactions, p. 85-102. In R. Pecora (ed.), Dynamic Light Scattering: Applications to Photon Correlation Spectroscopy. Plenum Press, New York, N.Y.

175. Raiders, R. A., M. J. McInerney, D. E. Revus, H. M. Torbati, R. M. Knapp, and G. E. Jenneman. 1986. Selectivity and depth of microbial plugging in Berea sandstone cores. J. Ind. Microbiol. 1:195-203.

176. Rajagopalan, R., and C. Tien. 1976. Trajectory analysis of deep-bed filtration with the sphere-in-cell porous media model. J. Am. Inst. Chem. Eng. 22:525-533.

177. Reddy, H. L., and R. M. Ford. 1996. Analysis of biodegradation and bacterial transport: comparison of models with kinetic and equilibrium bacterial adsorption. J. Contam. Hydrol. 22:271-287.

178. Redman, J. A., S. B. Grant, T. M. Olson, J. M. Adkins, J. L. Jackson, M. S. Castillo, and W. A. Yanko. 1999. Physicochemical mechanisms responsible for the filtra- tion and mobilization of a filamentous bacteriophage in quartz sand. Water Res. 33:43-52.

179. Redman, J. A., S. B. Grant, T. M. Olson, M. E. Hardy, and M. K. Estes. 1997. Filtration of recombinant Norwalk virus particles and bacteriophage MS2 in quartz sand: importance of electrostatic interactions. Environ. Sci. Technol. 31:3378-3383.

180. Rehmann, L. L. C., C. Welty, and R. W. Harvey. 1999. Stochastic analysis of virus transport in aquifers. Water Resour. Res. 35:1987-2006.

181. Ren, J., A. I. Packman, and C. Welty. 2000. Correlation of colloid collision efficiency with hydraulic conductivity of silica sands. Water Resour. Res. 36:24932500.

182. Reynolds, P. J., P. Sharma, G. E. Jenneman, and M. J. McInerney. 1989. Mechanisms of microbial movement in subsurface materials. Appl. Environ. Microbiol. 55: $2280-2286$

183. Rice, K. C., and G. M. Hornberger. 1998. Comparison of hydrochemical tracers to estimate source contributions to peak flow in a small, forested, headwater catchment. Water Resour. Res. 34:1755-1766.

184. Rijnaarts, H. H. M., W. Norde, E. J. Bouwer, J. Lyklema, and A. J. B. Zehnder. 1993. Bacterial adhesion under static and dynamic conditions. Appl. Environ. Microbiol. 59:3255-3265.

185. Rijnaarts, H. H. M., W. Norde, E. J. Bouwer, J. Lyklema, and A. J. B. Zehnder. 1996. Bacterial deposition in porous media: effects of cell-coating, substratum hydrophobicity, and electrolyte concentration. Environ. Sci. Technol. 30:2877-2883.

186. Rijnaarts, H. H. M., W. Norde, E. J. Bouwer, J. Lyklema, and A. J. B. Zehnder. 1996. Bacterial deposition in porous media related to the clean bed collision efficiency and to substratum blocking by attached cells. Environ. Sci. Technol. 30:2869-2876.

187. Ripple, C. D., R. V. James, and J. Rubin. 1974. Packing-induced radial particle-size segregation: influence on hydrodynamic dispersion and water transfer measurements. Soil Sci. Soc. Am. J. 38:219-222.

188. Robertson, B. R., D. K. Button, and A. L. Koch. 1998. Determination of the biomasses of small bacteria at low concentrations in a mixture of species with forward light scatter measurements by flow cytometry. Appl. Environ. Microbiol. 64:3900-3909.

189. Rossi, P., A. Decarvalhodill, I. Muller, and M. Aragno. 1994. Comparative tracing experiments in a porous aquifer using bacteriophages and fluorescent dye on a test field located at Wilerwald (Switzerland) and simultaneously surveyed in detail on a local scale by radiomagneto-tellury (12-240 kHz). Environ. Geol. 23:192200.

190. Rossi, P., N. Dorfliger, K. Kennedy, I. Muller, and M. Aragno. 1998. Bacteriophages as surface and ground water tracers. Hydrol. Earth Syst. Sci. 2:101-110.

191. Rothmel, R. K., R. W. Peters, E. St. Martin, and M. F. DeFlaun. 1998. Surfactant foam bioaugmentation technology for in situ treatment of TCE-DNAPLs. Environ. Sci. Technol. 32:1667-1675.

192. Rutter, P. R., and P. Vincent. 1980. The adhesion of microorganisms to surfaces: physicochemical aspects, p. 79-92. In R. C. W. Berkeley, J. M. Lynch, J. Melling, P. R. Rutter, and P. Vincent (ed.), Microbial Adhesion to Surfaces. Ellis Horwood Ltd., Chichester, United Kingdom.

193. Ryan, J. N., M. Elimelech, R. A. Ard, R. W. Harvey, and P. R. Johnson. 1999. Bacteriophage PRD1 and silica colloid transport and recovery in an iron oxide-coated sand aquifer. Environ. Sci. Technol. 33:63-73. 
194. Salanitro, J. P., G. E. Spinnler, C. C. Neaville, P. M. Maner, S. M. Stearns, and P. C. Johnson. 1999. Demonstration of the enhanced MTBE bioremediation (EMB) in situ process. In Proceedings of the 5th International Symposium on In Situ and On Site Bioremediation.

195. Schafer, A., H. Harms, and A. J. B. Zehnder. 1998. Bacterial accumulation at the air-water interface. Environ. Sci. Technol. 32:3704-3712.

196. Schafer, A., P. Ustohal, H. Harms, F. Stauffer, T. Dracos, and A. J. B. Zehnder. 1998. Transport of bacteria in unsaturated porous media. J. Contam. Hydrol. 33: 149-169.

197. Schijven, J. F., W. Hoogenboezem, S. M. Hassanizadeh, and J. H. Peters. 1999. Modeling removal of bacteriophages MS2 and PRD1 by dune recharge at Castricum, Netherlands. Water Resour. Res. 35:1101-1111.

198. Scholl, M. A., and R. W. Harvey. 1992. Laboratory investigations on the role of sediment surface and groundwater chemistry in transport of bacteria through a contaminated sandy aquifer. Environ. Sci. Technol. 26: 1410-1417.

199. Scholl, M. A., A. L. Mills, J. S. Herman, and G. M. Hornberger. 1990. The influence of mineralogy and solution chemistry on the attachment of bacteria to representative aquifer materials. J. Contam. Hydrol. 6:321336.

200. Shales, S. W., and S. Kumarasingham. 1987. Bacterial transport through porous solids: interactions between $\mathrm{Mi}$ crococcus luteus cells and sand particles. J. Ind. Microbiol. $2: 219-227$

201. Sharma, P. K., and M. J. McInerney. 1994. Effect of grain size on bacterial penetration, reproduction, and metabolic activity in porous-glass bead chambers. Appl. Environ. Microbiol. 60:1481-1486.

202. Sharma, P. K., M. J. McInerney, and R. M. Knapp. 1993. In situ growth and activity and modes of penetration of Escherichia coli in unconsolidated porous materials. Appl. Environ. Microbiol. 59:3686-3694.

203. Simoni, S. F., T. N. P. Bosma, H. Harms, and A. J. B. Zehnder. 2000. Bivalent cations increase both the subpopulation of adhering bacteria and their adhesion efficiency in sand columns. Environ. Sci. Technol. 34:10111017.

204. Simoni, S. F., H. Harms, T. N. P. Bosma, and A. J. B. Zehnder. 1998. Population heterogeneity affects transport of bacteria through sand columns at low flow rates. Environ. Sci. Technol. 32:2100-2105.

204a.Simoni, S. F., A. Schafer, H. Harms, and A. J. B. Zehnder. Factors affecting mass transfer limited biodegradation in saturated porous media. J. Contam. Hydrol., in press.

205. Sirokman, G., T. Wilson, and J. W. Hastings. 1995. A bacterial luciferase reaction with a negative temperature coefficient attributable to protein-protein interaction. Biochemistry 34:13074-13081.

206. Sjollema, J., H. J. Busscher, and A. H. Weerkamp. 1989. Experimental approaches for studying adhesion of microorganisms to solid substrata: applications and mass transport. J. Microbiol. Methods 9:79-90.

207. Smith, M. S., G. W. Thomas, R. E. White, and D. Ritonga. 1985. Transport of Escherichia coli through intact and disturbed soil columns. J. Environ. Qual. 14: $87-91$.

208. Smith, R. L., R. W. Harvey, and D. R. Leblanc. 1991. Importance of closely spaced vertical sampling in delineating chemical and microbiological gradients in groundwater studies. J. Contam. Hydrol. 7:285-300.

209. Stauffer, F., and T. Dracos. 1986. Experimental and numerical study of water and solute infiltration in layered porous media. J. Hydrol. 84:9-34.
210. Steffan, R. J., K. L. Sperry, M. T. Walsh, S. Vainberg, and C. W. Condee. 1999. Field-scale evaluation of in situ bioaugmentation for remediation of chlorinated solvents in groundwater. Environ. Sci. Technol. 33:27712781.

211. Story, S. P., P. S. Amy, C. W. Bishop, and F. S. Colwell. 1995. Bacterial transport in volcanic tuff cores under saturated flow conditions. Geomicrobiol. J. 13:249-264.

212. Straub, T. M., I. L. Pepper, and C. P. Gerba. 1995. Comparison of PCR and cell culture for detection of enteroviruses in sludge-amended field soils and determination of their transport. Appl. Environ. Microbiol. 61: 2066-2068.

213. Strong-Gunderson, J. M., and A. V. Palumbo. 1997. Laboratory studies identify a colloidal groundwater tracer: implications for bioremediation. FEMS Microbiol. Lett. 148:131-135.

214. Sun, Y., J. N. Petersen, J. Bear, T. P. Clement, and B. S. Hooker. 1999. Modeling microbial transport and biodegradation in a dual-porosity system. Transp. Porous Media 35:49-65.

215. Sutton, D. J., Z. J. Kabala, D. E. Schaad, and N. C. Ruud. 2000. The dipole-flow test with a tracer: a new single-borehole tracer test for aquifer characterization. J. Contam. Hydrol. 44:71-101.

216. Tan, Y., J. T. Gannon, P. Baveye, and M. Alexander. 1994. Transport of bacteria in an aquifer sand: experiments and model simulations. Water Resour. Res. 30: 3243-3252.

217. Taylor, S. W., and P. R. Jaffe. 1990. Substrate and biomass transport in a porous medium. Water Resour. Res. 26:2181-2194.

218. Thompson, S. S., and M. V. Yates. 1999. Bacteriophage inactivation at the air-water-solid interface in dynamic batch systems. Appl. Environ. Microbiol. 65:1186-1190.

219. Toran, L., and A. V. Palumbo. 1992. Colloid transport through fractured and unfractured laboratory sand columns. J. Contam. Hydrol. 9:289-303.

220. Trevors, J. T., J. D. van Elsas, L. S. van Overbeek, and M. E. Starodub. 1990. Transport of a genetically engineered Pseudomonas fluorescens strain through a soil microcosm. Appl. Environ. Microbiol. 56:401-408.

221. Troussellier, M., C. Courties, P. Lebaron, and P. Servais. 1999. Flow cytometric discrimination of bacterial populations in seawater based on SYTO 13 staining of nucleic acids. FEMS Microbiol. Ecol. 29:319-330.

222. Unge, A., R. Tombolini, L. Molbak, and J. K. Jansson. 1999. Simultaneous monitoring of cell number and metabolic activity of specific bacterial populations with a dual $g f p-l u x A B$ marker system. Appl. Environ. Microbiol. 65:813-821.

223. Unge, A., R. Tombolini, A. Moller, and J. K. Jansson. 1997. Optimization of GPF as a marker for detection of bacteria in environmental samples, p. 391-394. In J. W. Hastings, L. J. Kricka, and P. E. Stanley (ed.), Bioluminescence and Chemiluminescence: Molecular Reporting with Photons. John Wiley \& Sons, Ltd., Chichester, United Kingdom.

224. Unice, K. M., and B. E. Logan. 2000. Insignificant role of hydrodynamic dispersion on bacterial transport. J. Environ. Eng.-ASCE 126:491-500.

225. Vandevivere, P., and P. Baveye. 1992. Relationship between transport of bacteria and their clogging efficiency in sand columns. Appl. Environ. Microbiol. 58:25232530 .

226. Vandevivere, P., and P. Baveye. 1992. Saturated hydraulic conductivity reduction caused by aerobic bacteria in sand columns. Soil Sci. Soc. Am. J. 56:1-13. 
227. Vanelsas, J. D., J. T. Trevors, and L. S. Vanoverbeek. 1991. Influence of soil properties on the vertical movement of genetically-marked Pseudomonas fluorescens through large soil microcosms. Biol. Fertil. Soils 10:249_ 255.

228. van Oss, C. J. 1994. Interfacial Forces in Aqueous Media. Marcel Dekker, Inc., New York, N.Y.

229. van Oss, C. J., and C. F. Gillman. 1972. Contact angles and phagocytosis of non-opsonized bacteria. J. Reticuloendothel. Soc. 12:283-292.

230. van Oss, C. J., R. J. Good, and M. K. Chaudry. 1986. The role of van der Waals forces and hydrogen bonds in hydrophobic interactions between biopolymers and low energy surfaces. J. Colloid Interface Sci. 111:378-390.

231. Wan, J. M., T. K. Tokunaga, and C. F. Tsang. 1995. Bacterial sedimentation through a porous medium. Water Resour. Res. 31:1627-1636.

232. Wan, J. M., and J. L. Wilson. 1994. Visualization of the role of the gas-water interface on the fate and transport of colloids in porous media. Water Resour. Res. 30:1123.

233. Wan, J. M., J. L. Wilson, and T. L. Kieft. 1994. Influence of the gas-water interface on transport of microorganisms through unsaturated porous media. Appl. Environ. Microbiol. 60:509-516.

234. Wang, D. S., C. P. Gerba, and J. C. Lance. 1981. Effect of soil permeability on virus removal through soil columns. Appl. Environ. Microbiol. 42:83-88.

235. Wellings, F. M., A. L. Lewis, C. W. Mountain, and L. V. Pierce. 1975. Demonstration of virus in groundwater after effluent discharge into soil. Appl. Environ. Microbiol. 29:751-757.

236. Williams, V., and M. Fletcher. 1996. Pseudomonas fluorescens adhesion and transport through porous media are affected by lipopolysaccharide composition. Appl. Environ. Microbiol. 62:100-104.

237. Wilson, J. T., L. E. Leach, M. Henson, and J. N. Jones. 1986. In situ biorestoration as a ground water remediation technique. Ground Water Monit. Rev. 6:56-64.

238. Witt, M. E., M. J. Dybas, R. M. Worden, and C. S. Criddle. 1999. Motility-enhanced bioremediation of carbon tetrachloride-contaminated aquifer sediments. Environ. Sci. Technol. 33:2958-2964.

239. Wood, W. W., and G. G. Ehrlich. 1978. Use of baker's yeast to trace microbial movement in ground water. Ground Water 16:398-403.

240. Yadav, J. S., J. F. Quensen, J. M. Tiedje, and C. A. Reddy. 1995. Degradation of polychlorinated biphenyl mixtures (Aroclor-1242, Aroclor-1254, and Aroclor1260 ) by the white rot fungus Phanerochaete chrysosporium as evidenced by congener-specific analysis. Appl. Environ. Microbiol. 61:2560-2565.

241. Yao, K. M., M. T. Habibian, and C. R. O’Melia. 1971. Water and waste water filtration: concepts and applications. Environ. Sci. Technol. 5:1105-1112.

242. Yates, M. V., and C. P. Gerba. 1985. Factors controlling the survival of viruses in groundwater. Water Sci. Technol. 17:681-687.

243. Zhang, P., and W. P. Johnson. 1999. Rapid selective ferrographic enumeration of bacteria. J. Magn. Magn. Mater. 194:267-274.

244. Zhang, P., W. P. Johnson, and R. Rowland. 1999. Bacterial tracking using ferrographic separation. Environ. Sci. Technol. 33:2456-2460.

245. Zlotnik, V. A., and V. L. McGuire. 1998. Multi-level slug tests in highly permeable formations. 2. Hydraulic conductivity identification, method verification, and field applications. J. Hydrol. 204:283-296. 